\title{
An Approach to Identify Urban Waterlogging on a Deltaic Plain using ArcGIS on CHD based Flow Accumulation Models
}

Kaushik Bhaumik

Jadavpur University

Subhasish Das ( $\square$ subhasishju@gmail.com )

Jadavpur University https://orcid.org/0000-0002-6512-7454

\section{Research Article}

Keywords: Run-off, flow accumulation, waterlogging, gradient, aspect

Posted Date: June 10th, 2021

DOl: https://doi.org/10.21203/rs.3.rs-230413/v1

License: (c) (1) This work is licensed under a Creative Commons Attribution 4.0 International License.

Read Full License 


\title{
An Approach to Identify Urban Waterlogging on a Deltaic Plain using ArcGIS on CHD based Flow Accumulation Models
}

\author{
Kaushik Bhaumik ${ }^{\mathrm{a}}$ and Subhasish Das ${ }^{\mathrm{a}, *}$

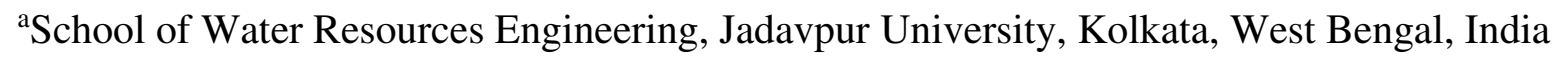 \\ *Corresponding Author. Email address: subhasish.das@jadavpuruniversity.in
}

\begin{abstract}
The gradient for any point on the land surface can be calculated using the digital-elevation model. Some empirical correlations are available to determine the gradient of any points. A few studies were conducted for hilly forest areas to determine the aspect and gradient of various points using computational hydrodynamics (CHD) based techniques. On a plain surface, the accuracy of such techniques was rarely verified. The application of such techniques for a plain surface is also extremely challenging for its small slope. Therefore, the prime objective of the present study is to find out an advanced technique to more accurately determine the gradient of various points on a plain surface which may help in determining the key areas affected by run-off, subsequent flow accumulation, and waterlogging. Here, Kolkata city as a deltaic plain surface is chosen for this study. Upto $600 \mathrm{~m} \times 600$ grid sizes are used on the DEM map to calculate the run-off pattern using a D8 algorithm method and second-order, third-order, and fourth-order finite difference techniques of CHD. After finding out the gradient, the run-off pattern is determined from relatively higher to lower gradient points. Based on the run-off pattern, waterlogging points of a plain surface are precisely determined. The results obtained from all the different methods are compared with one other as well as with the actual waterlogging map of Kolkata. It is found that the D8 algorithm and fourth-order finite-difference-technique are the most accurate while determining the waterlogging areas of a plain surface. Next, true gradients of waterlogging points are calculated manually to compare the calculated gradient points using each method. This is also done to determine the relationship and error between the true and calculated gradient of waterlogged points using various statistical analysis methods. The relationship between true and calculated gradients is observed from weak to strong if the D8 algorithm is replaced by the newly introduced fourth-order finite difference technique. Better accuracy and stronger relationships can be achieved by using a smaller grid size.
\end{abstract}

Keywords: Run-off; flow accumulation; waterlogging; gradient; aspect.

\section{Introduction}

Urban migration and agriculture can be considered as major causes of landscape change in numerous parts of the earth (Vizzari et al., 2018). With the increase in population, cities around the world are adopting flood water management measures to trim down the damage to the environment caused by impermeable run-off (Grey et al. 
2018). It is, therefore, necessary to determine the flow accumulation and thereby the waterlogging points in order to design a drainage system in the most effective way. Different techniques are used for evaluating the overall performance of the estimation, its accuracy and precision, and the self-reliance of estimation inaccuracy, as well as the magnitude of the slopes measured in the field (Warren et al. 2004).

Recently the digital-elevation-models or DEMs are used as input information for determining the flow directions in hydrological models for discharge simulation due to their high efficiency in presenting the spatial variability of the earth's surface (Beven and Kirkby 1979; Beasely et al. 1980; Fortin et al. 2001). The DEM accuracy was verified for different terrain parameters (Guo-an et al. 2001). Numerous grid DEM-based algorithms are also used and implemented in many GIS software programs for various hydrological analyses (O'Callaghan and Mark 1984; Fairfield and Leymarie 1991; Quinn et al. 1991; Bolstad and Stowe 1994; Cabral and Burges 1994; Tarboton 1997; Ashraf et al. 2011). Some empirical formulas are also used for determining the flow direction. Xue et al. (2016) used numerical simulation for determining the waterlogging area of an urban area.

Skidmore (1989) used six different methods to find out aspect and slope (gradient) from a commonly gridded DEM in a geographical region in southeast Australia having moderate topography. However, a definite study using the computational hydrodynamics (CHD) method to find out the slope on a plain surface was rarely done earlier.

The most widely used method to determine the run-off pattern in a surface is the D8 method described by Martz and Garbrecht (1992), The method was termed the deterministic eight neighbors (D8) technique by Fairfield and Leymarie (1991). Based on the fact that the water in every DEM grid-cell flows to only one of the neighboring cells, heading for a much larger drop. Some researchers (Zhao et al. 2009) used empirical formulas to determine the flow pattern.

Skidmore (1989) earlier used this method for a hilly forest area over a 100 square $\mathrm{km}$ area of southeast Australia. He used the following methods for calculating the gradient (slope) and the aspect of various points.

1 Conventional D8 algorithm (D8A)

2 Similar to the D8A method with the highest slope with the steepest fall or mount

3 Finite difference method of second order (FD2O)

4 Finite difference technique of third order (FD4O)

5 two methods using multi linear model using regression

These five types of methods were quantitatively compared by taking three consecutive horizontal and three consecutive vertical grid cells. The differences between the true aspect and the estimated aspect calculated using six methods as mentioned above were also calculated. The basic purpose of the study was to visualize these methods, which have a much smaller deviation than the true values of the slope and aspect. Skidmore (1989) concluded that there was almost no difference between third order method and multi regression models for calculating slope (gradient) and aspect. Between these methods, the FD3O method i.e. the finite difference technique of third order was found to be most accurate.

It is noteworthy to mention that using computational hydrodynamics to solve the partial differential equation and thereby determining the run-off pattern in a plain surface was hardly 
ever done earlier. The challenge to determine the flow accumulation and waterlogging areas on a plain surface is more than a semi-hilly or hilly surface because of the much smaller deviation of the elevations in between the consecutive grids. Here it is intended to find the usability of the following methods to determine the potential flow accumulation areas thereby the waterlogging areas on a plain surface. Like Skidmore, here first three methods are evaluated for a plain surface.

- Conventional D8 algorithm (D8A)

$\circ \quad$ Finite difference technique of second order (FD2O)

- Finite difference technique of third order (FD3O)

- Finite difference technique of fourth order (FD4O)

The fourth-order finite-difference technique (FD4O) is a new method, which was not used by Skidmore (1989) or others. The basic purpose of introducing this method is to check whether a more accurate result can be obtained than the second or third-order finite-difference technique.

Skidmore (1989) found the FD3O method to be the most accurate only for hilly forest areas. From the literature reviews, it is clear that till now any accurate technique was neither proposed nor verified to identify the waterlogging areas on a plain surface.

To find out the waterlogging area, one needs to first calculate the gradient values. After finding the waterlogging area of a plain surface, calculated gradient values have been compared for a few points (waterlogged area) with true values and thereby determined the Spearman rank coefficient to find out the relationship between these two variables. Based on the observations on area matching accuracy and better Spearman correlation values, the most appropriate method for determining flow accumulated and waterlogged areas have been recommended.

So, in conclusion, the prime objective of this study is to use four different methods D8A, FD2O, FD3O, and FD4O to find out the waterlogging area on a plain surface to develop further stormwater networks and related pumping systems. It is also important to find out which method is more accurate on a plain surface. Out of these four methods, it is also found out which method is the most suitable for a plain surface.

\section{Study area volition}

For the study area, the deltaic city Kolkata is chosen as a plain surface. The deltaic city Kolkata is the capital of West Bengal state in India as shown in Fig. 1. The megacity is situated on the lower Ganga-Bhagirathi Rivers plain, and the River Hooghly (a tributary of River Ganga) extends its western boundary from $22^{0} 28^{\prime}$ north to $22^{0} 37^{\prime} 30^{\prime \prime}$ north and $88^{\circ} 17^{\prime} 30^{\prime \prime}$ east to $88^{\circ} 25^{\prime}$ east covering around $187 \mathrm{sq}$. $\mathrm{km}$ area. This metro city is divided into 144 wards (including the addition of three more wards recently). Most of the plains are covered by the Hooghly River to the northwest and numerous canals such as Bagjola in the north, Belighata, and the central circular canal, and the Adi-Ganga and Tolly Nallah in the southern part, but most of these rivers and nalas have been silted up (John and Das 2020). The plain area of Kolkata is largely divided into nine numbers of drainage basins. Among these nine basins, three of them cater to western Kolkata and the remaining six of them serve the eastern portion. Total eleven numbers of sluice ways 
connecting the river Hooghly prevent the entry of many tidal waves during the worst events. This deltaic plain land is located at an average elevation of 9.1 meters above sea level, tilted to the south. The metropolis has several low-lying areas such as shallow waterbodies with marshes, many of which are remnants of the Bhagirathi river waterways. Megacity Kolkata is bounded north and east by the 24 Parganas (N) and in the south by the 24 Parganas (S) and the Howrah to the west. The area encounters a tropical climate with the highest temperature of approx. $40^{\circ} \mathrm{C}$ and with a minimum temperature of about $10^{\circ} \mathrm{C}$, corresponding to a moderate rainfall of $165 \mathrm{~cm}$ where $70-80 \%$ of annual rainfall takes place between mid June to early September (John and Das 2020). The population of Kolkata based on the 2011 census was $4,496,694$ and the metropolitan population had 14,112,536 people in 2011. Mukhopadhyay (2004) and Paul (2009) reported an overall situation of terrible waterlogging problems in Kolkata city.

Though waterlogging has been a foremost trouble in all monsoons in Kolkata but large this plain area has evidenced a series of severe floods in the succeeding years of 1970, 1978, 1984, 1999, 2007, 2016 flooding densely or moderately populated plain areas in the central part of the city like Central Avenue, Bidhan Sarani, Sealdah, Amherst Street, Park Circus Connector, Bowbazar, Park Street, Suryasen Street and its connected areas and in the southern Kolkata including Jadavpur, Behala, Deshapriya Park. Gariahat (Dasgupta et al. 2012).

The cause of waterlogging nature in Kolkata is divided into the following categories (Banerjee 2018).

- Topography: A low-lying city on the shore of River Hooghly (average elevation of 9.1 meters above sea level) on the west and a wetland towards the east, several natural depressions, a layer of active clay. The city's natural gradient extends from west to east, with Hooghly outlining the western boundary. The central area of Kolkata city is like a bowl of soup with stormwater coming in from the neighbouring areas. Previously, the eastern part included wetlands and large swamps where stormwater could enter and were the natural sinks of the city's sewage system.

- Governance Issue: The Kolkata drainage system is perhaps the oldest one - probably no improvement after that has forced the city into a poorer condition. The high levels of siltation, inadequate and improper sewer arrangements, unscientific canals (nalas) are the main issues. Heavy siltation has greatly decreased the transport capacity of River Hooghly. Dredging is predominantly perfunctory and yet, it is not possible to divert the city's stormwater by pumping into the Hooghly River during the high tides. Given all these issues that are the reason for waterlogging, it is certain that the people of Kolkata have to stop living underwater every few hours of heavy rain.

- Anthropogenic Issue: Increase in population density, urbanisation and a huge amount of concretization, reduction in greenery and water body, lack of awareness of abundance have led to urban flood problems.

- Climatic Condition: Climate change is one of the reasons for urban flooding. 


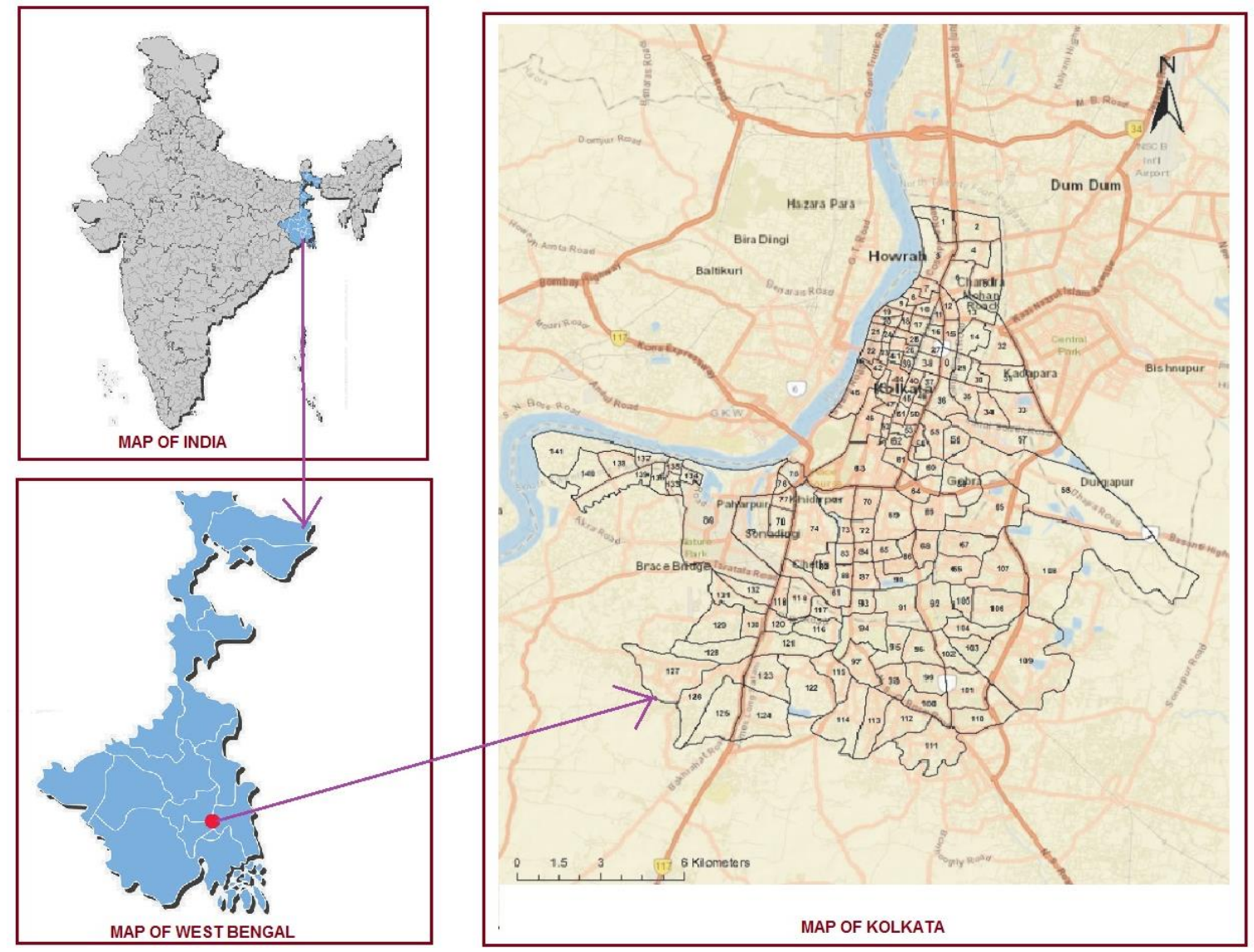

Fig. 1. Study area

\section{Research methodology}

In this study, we have used the DEM of Kolkata city as a plain surface. The ultimate goal of this study is to identify the most accurate method for finding out the waterlogging areas of a plain area like Kolkata. The DEM grid contains the structure of the matrix data and each matrix node stores the geographic elevation of every pixel. DEMs are readily available and easy to use which is why they have seen widespread use in the various analyses of hydrologic problems (Moore et al., 1991. The methods describe various means of calculating the slope of each grid point of DEM point and then calculating runoff and waterlogging patterns.

\subsection{D8 algorithm technique (D8A)}

In this method, the gradient is calculated as the path to the highest drop from the centre cell to the nearest eight cells as given in Fig. 2 wherein the central point elevation magnitude of the $9 \times 9$ matrix is denoted as $z_{i, j, k}$ such that $i, j$ and $k$ symbolize the directional nodes along with horizontal (x), crosswise $(y)$ and elevation wise $(z)$ directions, respectively. The corresponding gradient calculation formula is given in equation 1 .

The formula is,

$$
\text { Gradient }=\max \left[\left\{z_{i, j, k}-z_{i-1, j-1, k}\right\},\left\{z_{i, j}-z_{i-1, j, k}\right\}, \ldots,\left\{z_{i, j, k}-z_{i+1, j+1, k}\right\}\right]
$$


199

200

201

202

203

204

205

206

207

208

209

210

211

212

213

214

215

216

217

218

219

220

221

222

224

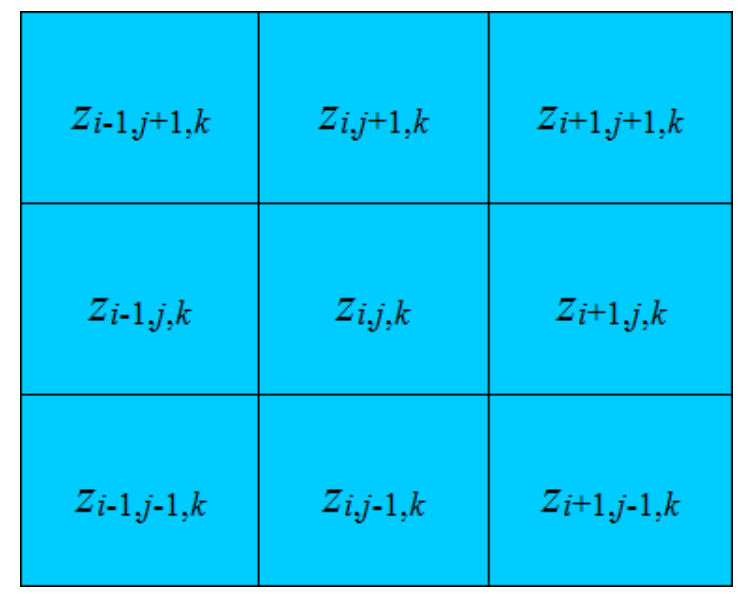

Fig. 2. A 9×9 cell matrix.

For the terminal grid points of the DEM map; the nearest point outside the DEM of Kolkata has been considered for calculation purposes. Using this method gradient is calculated for all the points of the DEM. The run-off pattern is calculated by comparing the difference in the gradient of any value and eight nearest cells. The maximum difference between any of these two points is to the direction of run-off and accordingly, the run-off pattern is calculated for all the points.

\subsection{Finite difference technique of second order (FD2O)}

Our second method deals with finite difference of second order (FD2O) model by which the gradient is calculated. The first step is to calculate $(\delta z / \delta x)_{i, j, k}$, and $(\delta z / \delta y)_{i, j, k}$ using the secondorder finite- difference technique. Equations 2-3 are explained below.

$$
\begin{aligned}
& {\left[\frac{\delta z}{\delta x}\right]_{i, j, k} \approx \frac{z_{i+1, j, k}-z_{i-1, j, k}}{2 \Delta x}} \\
& {\left[\frac{\delta z}{\delta y}\right]_{i, j, k} \approx \frac{z_{i, j+1, k}-z_{i, j-1, k}}{2 \Delta y}}
\end{aligned}
$$

Here $\Delta x$ is the smallest spacing between grid positions in the plain $(x)$ direction, spacing $\Delta y$ is the smallest distance between the grid points in the crosswise $(y)$ path, and $i$ and $j$ indices are must not the side-line columns or rows. Here, $k$ is the elevation $(z)$ wise index.

For the points at the end of a row of columns, equations 4-5 obtained using a polynomial technique with the second-order difference (Anderson 1995), have been used to calculate gradient components.

$$
\begin{array}{ll}
{\left[\frac{\delta z}{\delta x}\right]_{i=n, j, k} \approx \frac{-3 z_{i=n, j, k}+4 z_{i=n+1, j, k}-z_{i=n+2, j, k}}{2 \Delta x}} & \text { where } n=1,2,3, \ldots \ldots \\
{\left[\frac{\delta z}{\delta y}\right]_{i, j=n, k} \approx \frac{-3 z_{i, j=n, k}+4 z_{i, j=n+1, k}-z_{i, j=n+2, k}}{2 \Delta y}} & \text { where } n=1,2,3, \ldots \ldots
\end{array}
$$

The gradient $(\tan G)$ is then defined as 


$$
\tan G=\sqrt{\left[\frac{\delta z}{\delta x}\right]^{2}+\left[\frac{\delta z}{\delta y}\right]^{2}}
$$

Again similar to the D8A method, the gradient is calculated for all the points in a grid. The run-off pattern is calculated by comparing the difference in the gradient of any value and eight nearest cells. The maximum difference between any of these two points is the direction of run-off and thus it is calculated for all the points.

\subsection{Finite difference technique of third order (FD3O)}

The next method is the finite difference of third order (FD3O) technique by which the gradient is calculated. Again, $(\delta z / \delta x)_{i, j, k}$ and $(\delta z / \delta y)_{i, j, k}$ are calculated by using the following equations.

$$
\begin{aligned}
& {\left[\frac{\delta z}{\delta x}\right]_{i, j, k} \approx \frac{z_{i+1, j+1, k}-z_{i-1, j+1, k}+2\left(z_{i+1, j, k}-z_{i-1, j, k}\right)+z_{i+1, j-1, k}-z_{i-1, j-1, k}}{8 \Delta x}} \\
& {\left[\frac{\delta z}{\delta y}\right]_{i, j, k} \approx \frac{z_{i+1, j+1, k}-z_{i+1, j-1, k}+2\left(z_{i, j+1, k}-z_{i, j-1, k}\right)+z_{i-1, j+1, k}-z_{i-1, j-1, k}}{8 \Delta y}}
\end{aligned}
$$

For the points at the end of a row of columns, equations 9-10 obtained using the polynomial technique with the third-order difference, have been used to calculate gradient components.

$$
\left[\frac{\delta z}{\delta x}\right]_{i=n, j, k} \approx \frac{-11 z_{i=n, j, k}+18 z_{i=n+1, j, k}-9 z_{i=n+2, j, k}+2 z_{i=n+3, j, k}}{6 \Delta x} \quad \text { where } n=1,2,3, \ldots \ldots
$$

$$
\left[\frac{\delta z}{\delta y}\right]_{i, j=n, k} \approx \frac{-11 z_{i, j=n, k}+18 z_{i, j=n+, k}-9 z_{i, j=n+2, k}+2 z_{i, j=n+3, k}}{6 \Delta y} \quad \text { where } n=1,2,3, \ldots
$$

The gradient is calculated using equation 6 as described before. Again, similar to the D8A method, gradient $\tan G$ is calculated for all the points in the zone.

\subsection{Finite difference technique of fourth order (FD4O)}

The next method is the finite difference of fourth order (FD4O) technique by which the gradient is calculated. The first step is to calculate $(\delta z / \delta x)_{i, j, k}$ and $(\delta z / \delta y)_{i, j, k}$ which are calculated by the following equations 11-12 derived using CHD and Taylor series technique.

$$
\left[\frac{\delta z}{\delta x}\right]_{i, j, k} \approx \frac{-z_{i+2, j, k}+8 z_{i+1, j, k}-8 z_{i-1, j, k}+z_{i-2, j, k}}{12 \Delta x}
$$

$$
\left[\frac{\delta z}{\delta y}\right]_{i, j, k} \approx \frac{-z_{i, j+2, k}+8 z_{i, j+1, k}-8 z_{i, j-1, k}+z_{i, j-2, k}}{12 \Delta y}
$$

For the points at the end of a row of columns, equations 13-14 obtained using the polynomial technique with the fourth-order difference, have been used to calculate gradient components.

$\left[\frac{\delta z}{\delta x}\right]_{i=n, j, k}=\frac{-25 z_{i=n, j, k}+48 z_{i=n+1, j, k}-36 z_{i=n+2, j, k}+16 z_{i=n+3, j, k}-3 z_{i=n+4, j, k}}{12 \Delta x} \quad$ where $n=1,2,3, \ldots \ldots$ 
$\left[\frac{\delta z}{\delta y}\right]_{i, j=n, k}=\frac{-25 z_{i, j=n, k}+48 z_{i, j=n+1, k}-36 z_{i, j=n+2, k}+16 z_{i, j=n+3, k}-3 z_{i, j=n+4, k}}{12 \Delta y} \quad$ where $n=1,2,3, \ldots$

The gradient and run-off pattern are again calculated as described above.

\section{Results and Discussion}

As per the research methodology described in the earlier section, first, we need to determine the elevation value. Raster file was extracted from United-States-Geological-Survey Earth Explorer. To extract the elevation value from the ASTER Global DEM of Kolkata, ArcGIS v10.3 software was used. A spatial resolution of $28.58 \times 30.76 \mathrm{~m}$ was used. Initially, a $1200 \mathrm{~m}$ $\times 1200 \mathrm{~m}$ grid is used to determine the elevation points of Kolkata covering almost $22800 \mathrm{~m}$ $\times 19200 \mathrm{~m}$ plain surface. In the following picture, the DEM of Kolkata divided into a $1200 \mathrm{~m}$ $\times 1200 \mathrm{~m}$ grid is shown in Fig. 3. The major areas of Kolkata are also shown in this Fig. 3 .

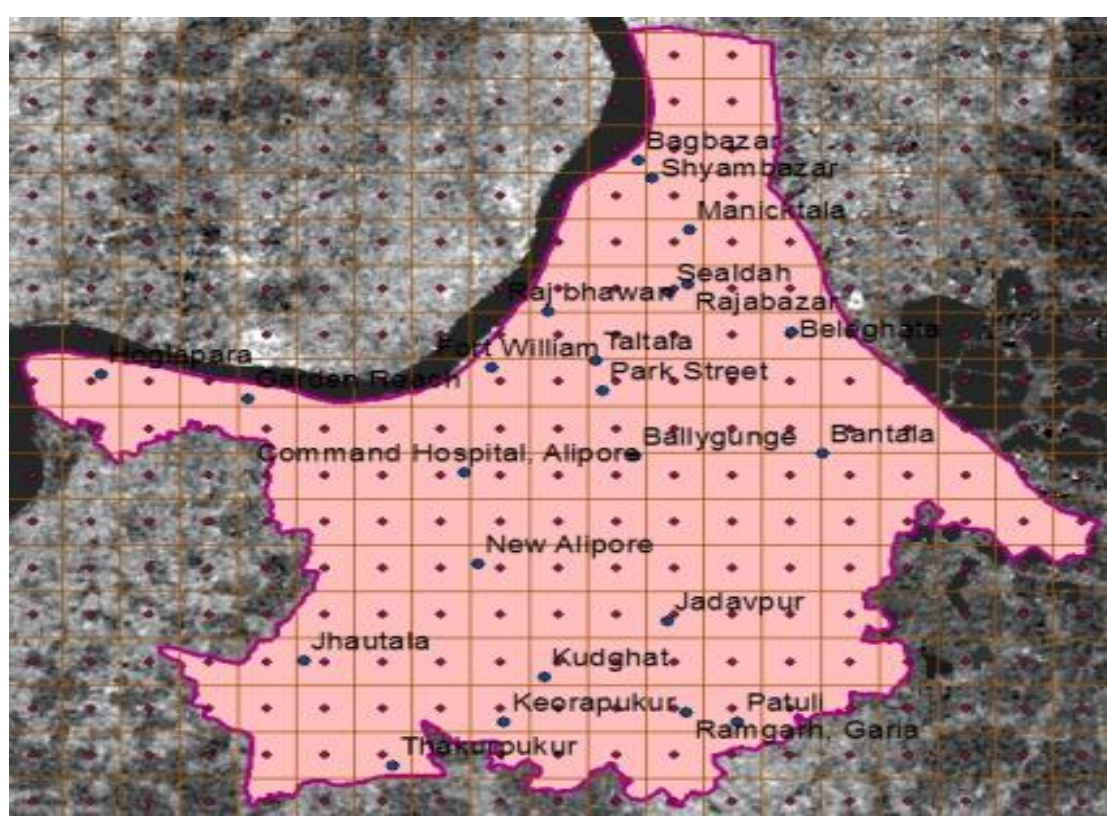

Fig. 3. DEM map of Kolkata using a $1200 \mathrm{~m} \times 1200 \mathrm{~m}$ grid.

The elevation data of various points of Kolkata is extracted from the software FishNET is indicated below. Using the elevation data from Fig. 4, the gradient is calculated using the D8A and FD2O methods.

In the D8A method, initially, the $1200 \mathrm{~m} \times 1200 \mathrm{~m}$ grid has been used. This is explained using equation 1. In Fig. 4, the elevation data of Kolkata has been extracted from DEM. All the elevation values indicated here are respecting the mean-sea-level. The cells as highlighted in Fig. 4 are used for showing sample calculation to determine the gradient value of a point. The elevation value of the center cell is highlighted in yellow $(z i, j, k)$ is 14 . Differences from the adjacent cells are calculated below.

\section{Sample Case 1:}

$$
14-08=6
$$$$
14-05=9
$$ 


$$
\begin{array}{ll}
14-11=3 & 14-08=6 \\
14-11=3 & 14-13=1 \\
14-09=5 & 14-09=5
\end{array}
$$

284 From sample case 1, the highest of these difference grid values is 9. Hence the gradient of 285 this point having an elevation value as ' 14 ' is 9 . Using the above principle, the gradient of all 286 points is calculated and shown in Fig. 5.

287 After calculating the gradient points, next, the flow direction is determined. The 288 sample calculation is indicated below for the highlighted points in Fig. 5 to determine the 289 flow direction.

290

\begin{tabular}{|c|c|c|c|c|c|c|c|c|c|c|c|c|c|c|c|c|c|}
\hline & & & & & & & & & & 0 & 7 & & \multirow{6}{*}{ 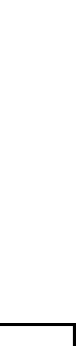 } & \multirow{7}{*}{ 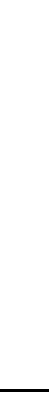 } & \multirow{8}{*}{. } & & \\
\hline & & & & & & & & & & 0 & 8 & & & & & & \\
\hline & & & & & & & & & & 0 & 10 & & & & & & \\
\hline & & & & & & & & & 0 & 9 & 6 & & & & & & \\
\hline & & & & & & & & 7 & 8 & 11 & 11 & 5 & & & & & \\
\hline & & & & & & & & 0 & 9 & 14 & 5 & 7 & & & & & \\
\hline & & & & & & & 6 & 8 & 8 & 13 & 9 & 6 & 7 & & & & \\
\hline 6 & 9 & 10 & 13 & 0 & 0 & 0 & 12 & 8 & 15 & 14 & 9 & 7 & 7 & 3 & & & \\
\hline 2 & 2 & 5 & 2 & 7 & 9 & 4 & 12 & 12 & 14 & 9 & 7 & 7 & 8 & 3 & 7 & & \\
\hline & & & 9 & 6 & 6 & 7 & 6 & 13 & 10 & 14 & 6 & 10 & 4 & 0 & 7 & 5 & \\
\hline & & & 0 & 8 & 7 & 5 & 13 & 10 & 12 & 13 & 7 & 7 & 6 & 2 & 0 & 0 & 0 \\
\hline & & & & 4 & 8 & 9 & 11 & 11 & 8 & 8 & 11 & 9 & 6 & & & & \\
\hline & & & & 4 & 11 & 15 & 14 & 8 & 9 & 8 & 10 & 7 & 6 & & & & \\
\hline & & 5 & 7 & 4 & 8 & 12 & 6 & 13 & 13 & 12 & 10 & 6 & 6 & 2 & & & \\
\hline & & 5 & 6 & 9 & 10 & 8 & 2 & 7 & 11 & 11 & 10 & 11 & 4 & & & & \\
\hline & & & 4 & 7 & 6 & 9 & 3 & 9 & 7 & 8 & 8 & & & & & & \\
\hline
\end{tabular}

Fig. 4. Elevation data of Kolkata in $1200 \mathrm{~m} \times 1200 \mathrm{~m}$ grid. 


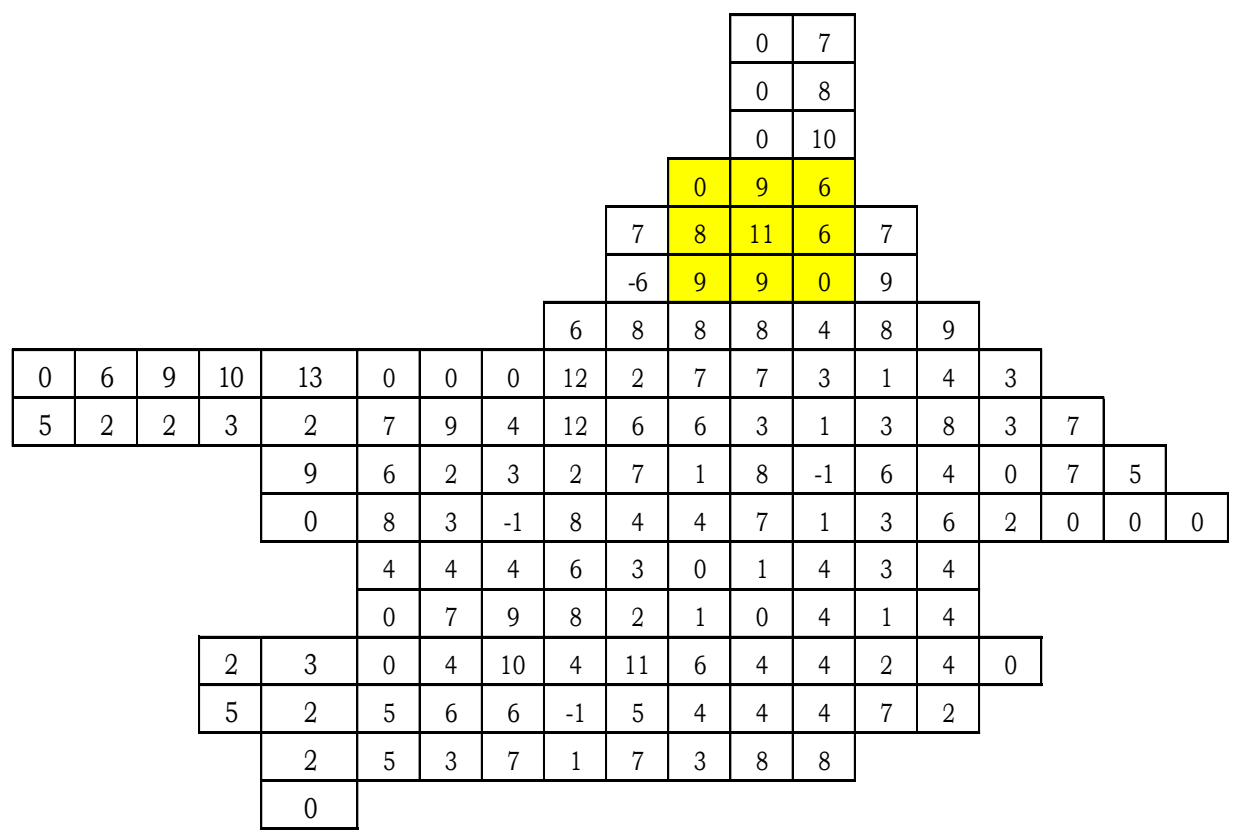

Fig. 5. Gradients of all points using the D8A method.

Sample Case 2:

$$
\begin{array}{ll}
11-00=11 & 11-06=05 \\
11-09=02 & 11-09=02 \\
11-06=05 & 11-09=02 \\
11-08=03 & 11-00=11
\end{array}
$$

298 Comparing the above values, it is evident that the maximum difference of the gradient value 299 of the adjacent cells is 11. Hence, the flow direction is expected towards the north-west or 300 south-east for case 1 . The calculation is repeated for the gradient points and the flow pattern 301 is shown in the next figure. 


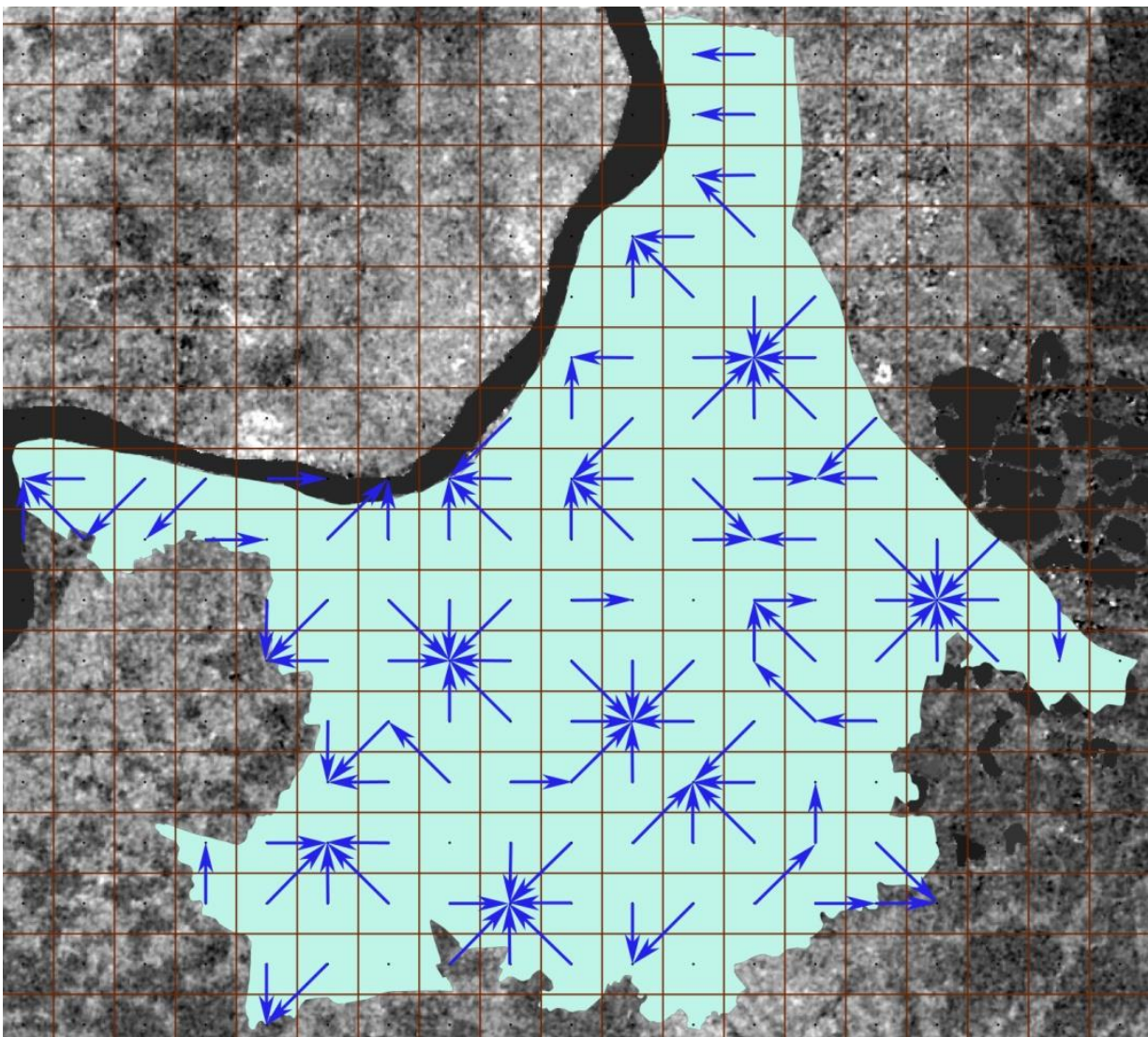

Fig. 6. Runoff pattern using the D8A method.

The FD2O method elucidates the second-order finite-difference technique. Here $1200 \mathrm{~m} \times$ $1200 \mathrm{~m}$ grid has been used. The elevation data of Kolkata is already indicated in Fig. 4. Using equations $2-5,(\delta z / \delta x)_{i, j, k}$ and $(\delta z / \delta y)_{i, j, k}$ values are calculated. Using the values $(\delta z / \delta x)_{i, j, k}$, and $(\delta z / \delta y)_{i, j, k}$ gradient of all elevation points have been calculated using equation 6 . The run-off pattern has been calculated similarly to the D8A method and shown below in Fig. 7.

From the analysis of the above two (2) methods i.e. D8A and FD2O methods, 312 it is found that the gradient of the respective points is not matching each other. 313 Therefore, the run-off pattern and waterlogging area of Kolkata cannot be determined 314 more accurately using a $1200 \mathrm{~m} \times 1200 \mathrm{~m}$ grid. Since the area of Kolkata is not much, 315 a better result is expected to be obtained if we use more closely spaced grids such as $800 \mathrm{~m} \times 800 \mathrm{~m}$ grid or even smaller like $600 \mathrm{~m} \times 600 \mathrm{~m}$ grid. 


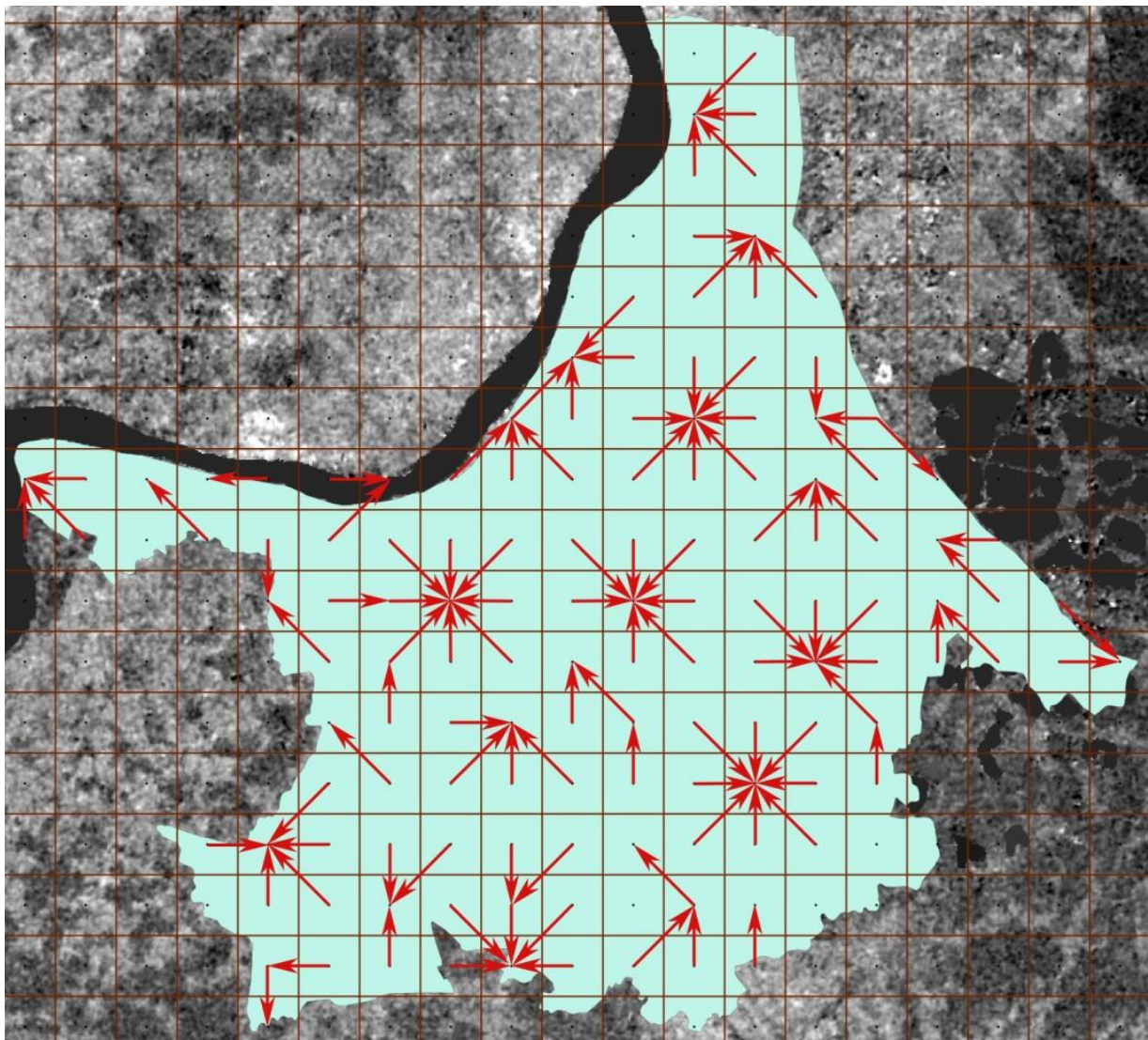

Fig. 7. Runoff pattern using the FD2O method.

Therefore, for better accuracy using the purpose using the FishNET tool of ArcGIS software, the entire DEM of Kolkata is divided into a $600 \mathrm{~m} \times 600 \mathrm{~m}$ grid as indicated in Fig. 8 below. The gradient of all the points and runoff patterns is calculated using the two methods explained above and also using the third and fourth-order differential methods (FD3O and FD4O). Later using all these methods waterlogging area of Kolkata is determined. Hence, we restrict the grid size with a $600 \mathrm{~m} \times 600 \mathrm{~m}$ grid and different calculations are done to calculate the gradient and thereby flow pattern and waterlogging area of Kolkata.

Elevation data extracted from the DEM using ArcGIS is indicated in Fig. 9. The gradient of the various points is then calculated of the above points and thus run-off pattern 


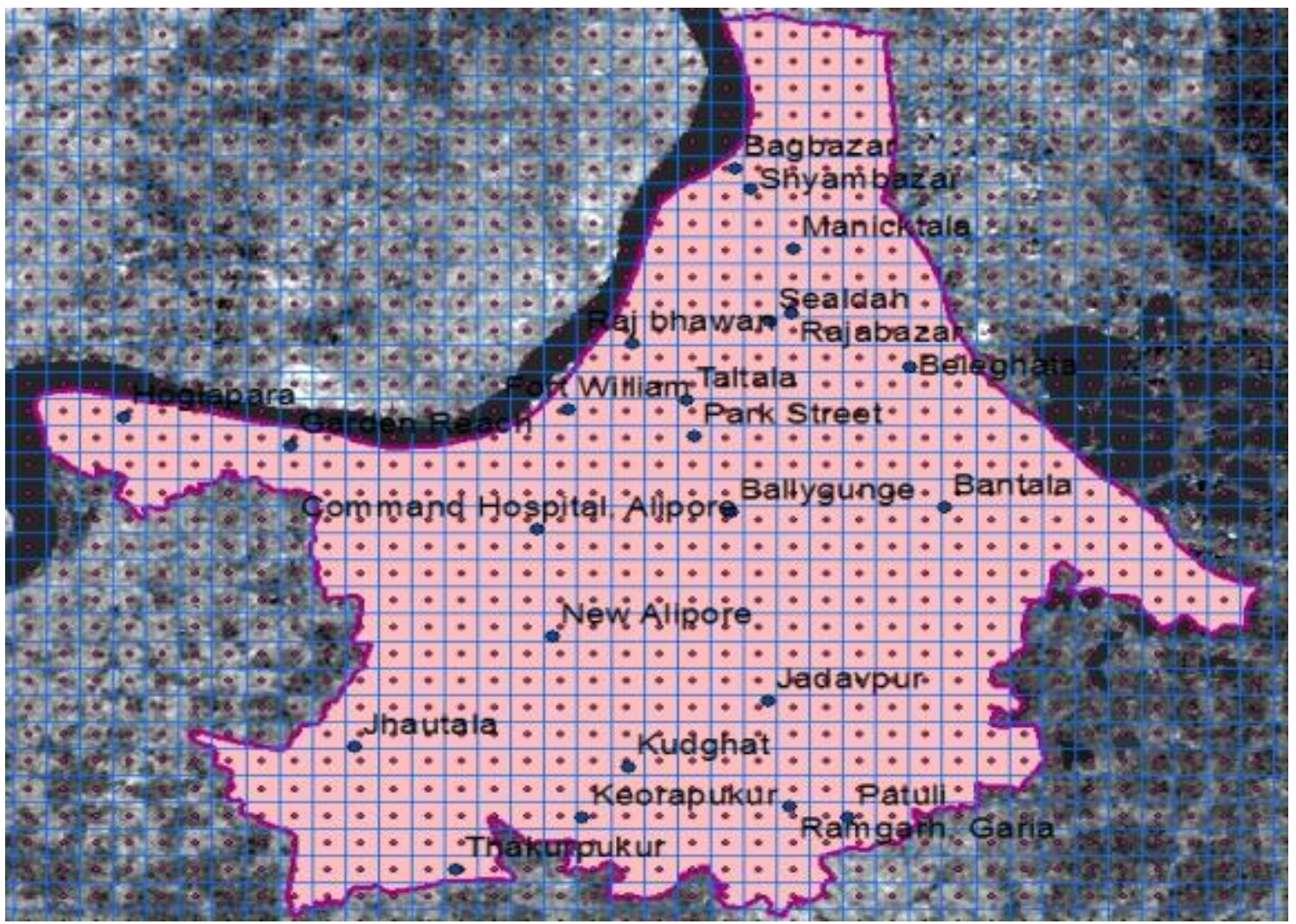

Fig. 8. DEM map of Kolkata using $600 \mathrm{~m} \times 600 \mathrm{~m}$ grid.

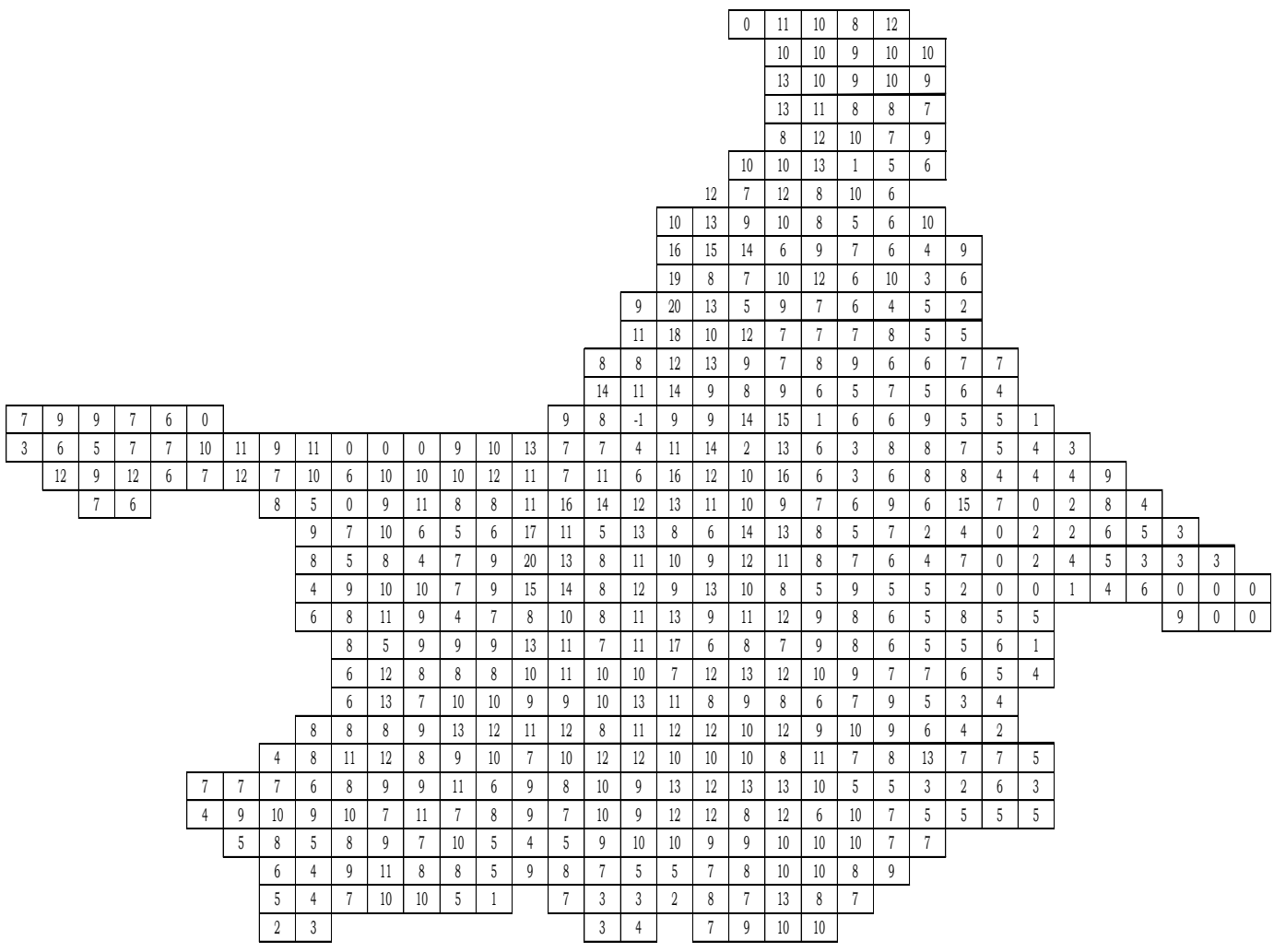

Fig. 9. Elevation data of Kolkata in $600 \mathrm{~m} \times 600 \mathrm{~m}$ grid. 
Elevation data of Kolkata in $600 \mathrm{~m} \times 600 \mathrm{~m}$ grid is tabulated in Fig. 9. Similar to the earlier method integer values are only considered for the elevation of different points. Here, we have used the D8A method to determine the flow pattern. This method is explained in equation 1. First, the gradient, $\tan G$ is calculated for all elevation points. The run-off pattern is then calculated by comparing the difference of gradient of any point and the next eight nearest cells and shown in Fig. 10.

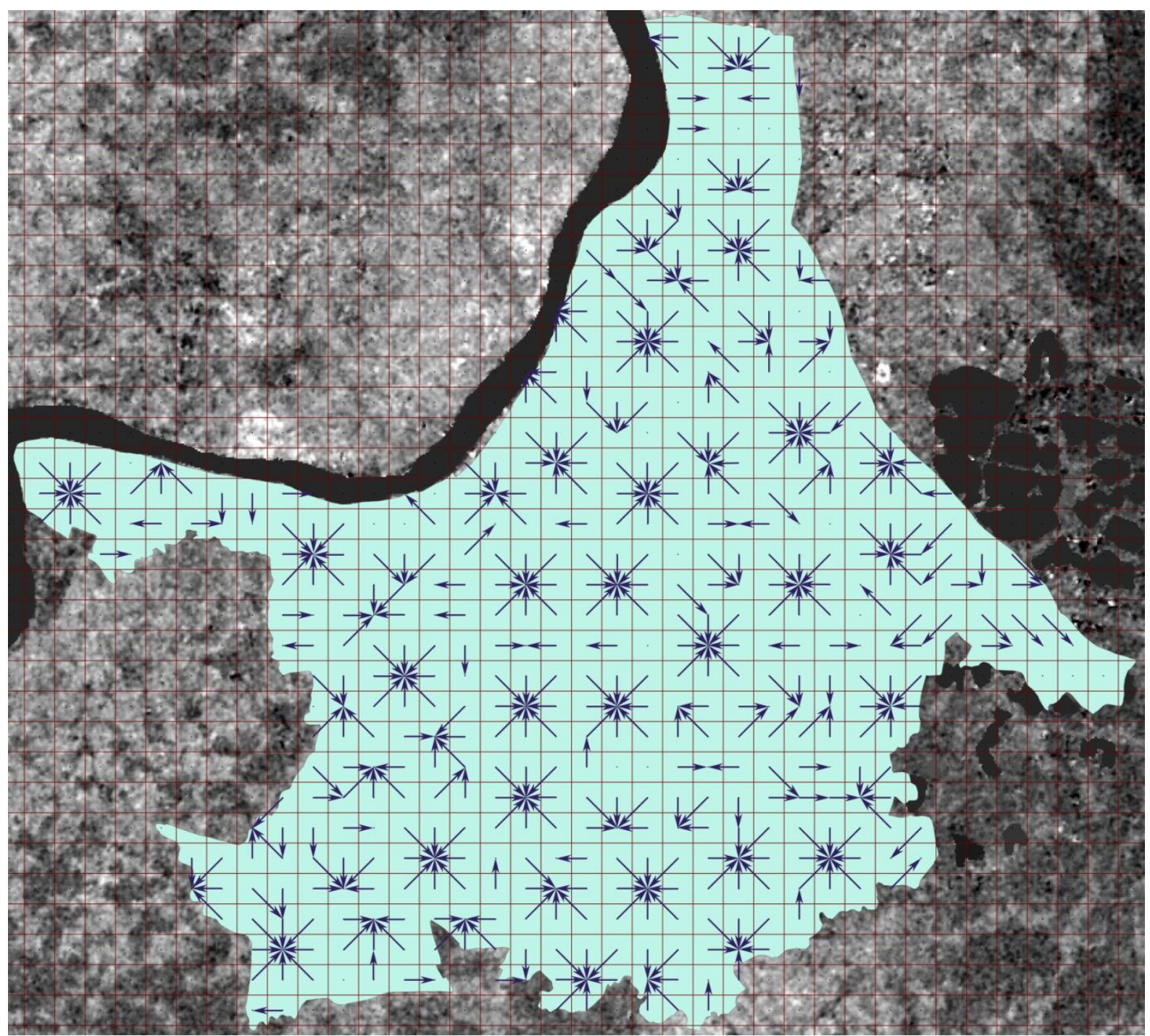

Fig. 10. Run-off pattern using D8A method.

(1)


Next, we have used the FD2O method for the estimation of run-off. The details of the calculation are already illustrated above. Here the valve of $\Delta x$ and $\Delta y$ is 361600 meters. Using the formula indicated in equations $2-5,(\delta z / \delta x)_{i, j, k}$ and $(\delta z / \delta y)_{i, j, k}$ are 362 calculated. Using the values of $(\delta z / \delta x)_{i, j, k}$, and $(\delta z / \delta y)_{i, j, k}$, gradients are calculated using 363 the formula described in equation 6 . The run-off pattern is calculated similarly to the 364 method described earlier and shown in (Fig. 11).

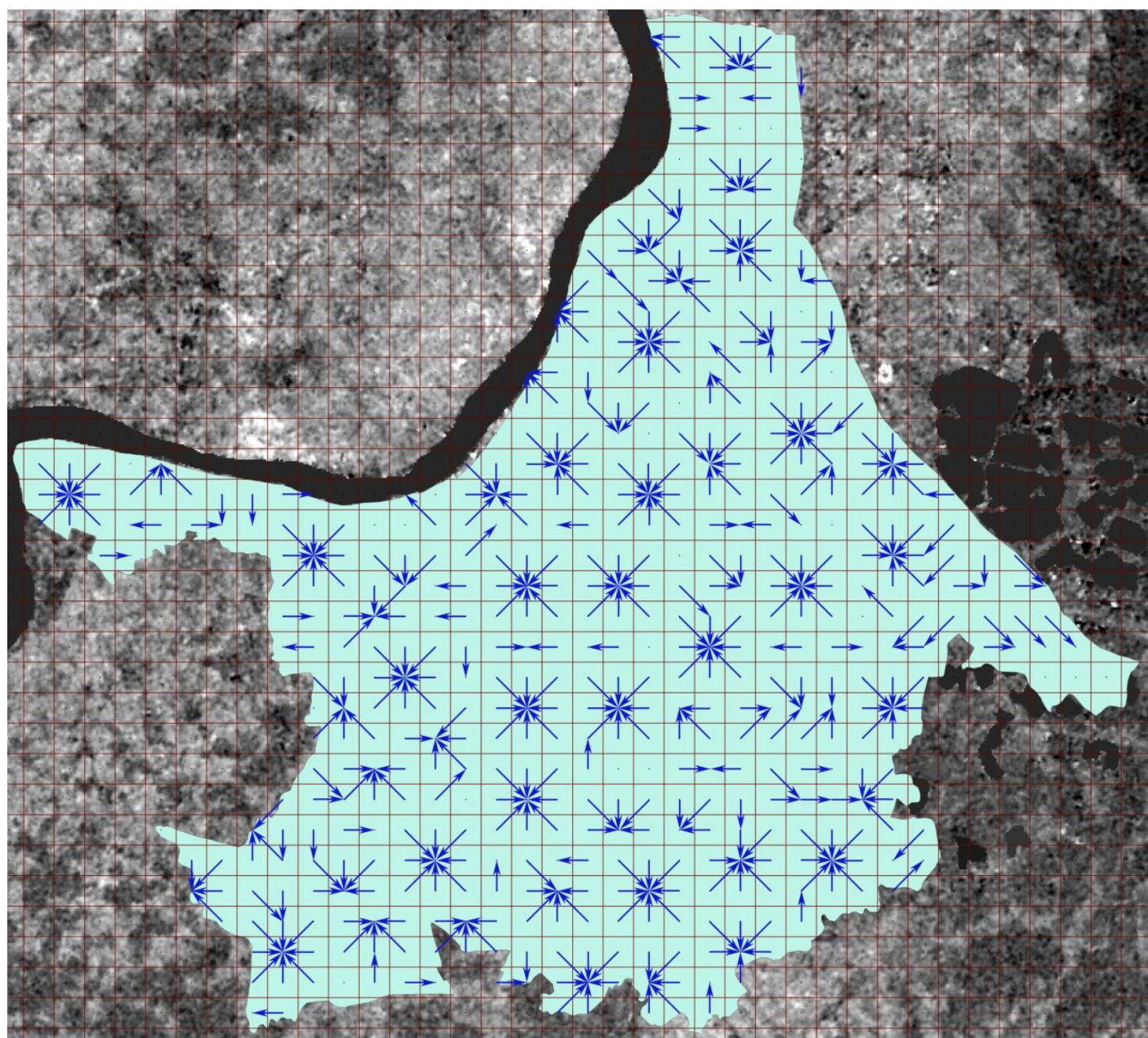

Fig. 11. Run-off pattern using FD2O method. 
378 Next, we have used the third-order finite-difference technique to calculate $(\delta z / \delta x)_{i, j, k}$ and $379(\delta z / \delta y)_{i, j, k}$ gradients of various points. The $(\delta z / \delta x)_{i, j, k}$ and $(\delta z / \delta y)_{i, j, k}$ values are calculated to 380 estimate the gradient points. After determining the gradient points, a run-off pattern is also 381 calculated and shown in the next figure (Fig. 12).

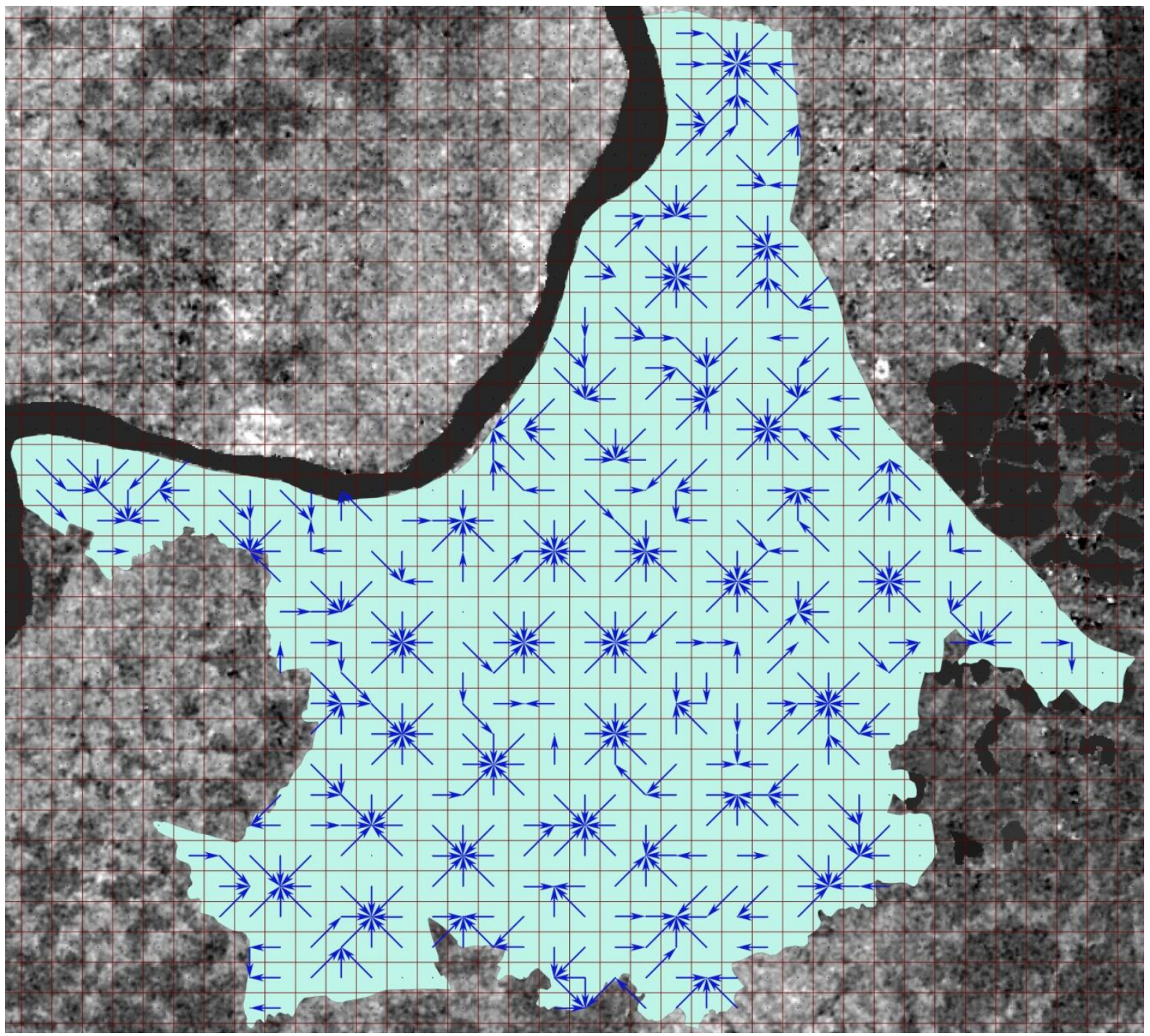

Fig. 12. Run-off pattern using FD3O method. 
396

397

398

399

400

401

402

403

Next, we have introduced a new method which is the fourth-order finite-difference technique using which gradient is calculated. Skidmore (1989) used D8A, FD2O, FD3O methods (partially) while calculating the gradient and aspect but never used the fourth-order finitedifference method (FD4O). In this method, $(\delta z / \delta x)_{i, j, k}$ and $(\delta z / \delta y)_{i, j, k}$ are calculated using the fourth-order finite-difference technique using equations 7-10. Using the values of $(\delta z / \delta x)_{i, j, k}$ and $(\delta z / \delta y)_{i, j, k}$, the gradient is calculated using the formula described in equation 6 . The runoff pattern is next determined and shown in the next picture (Fig. 13).

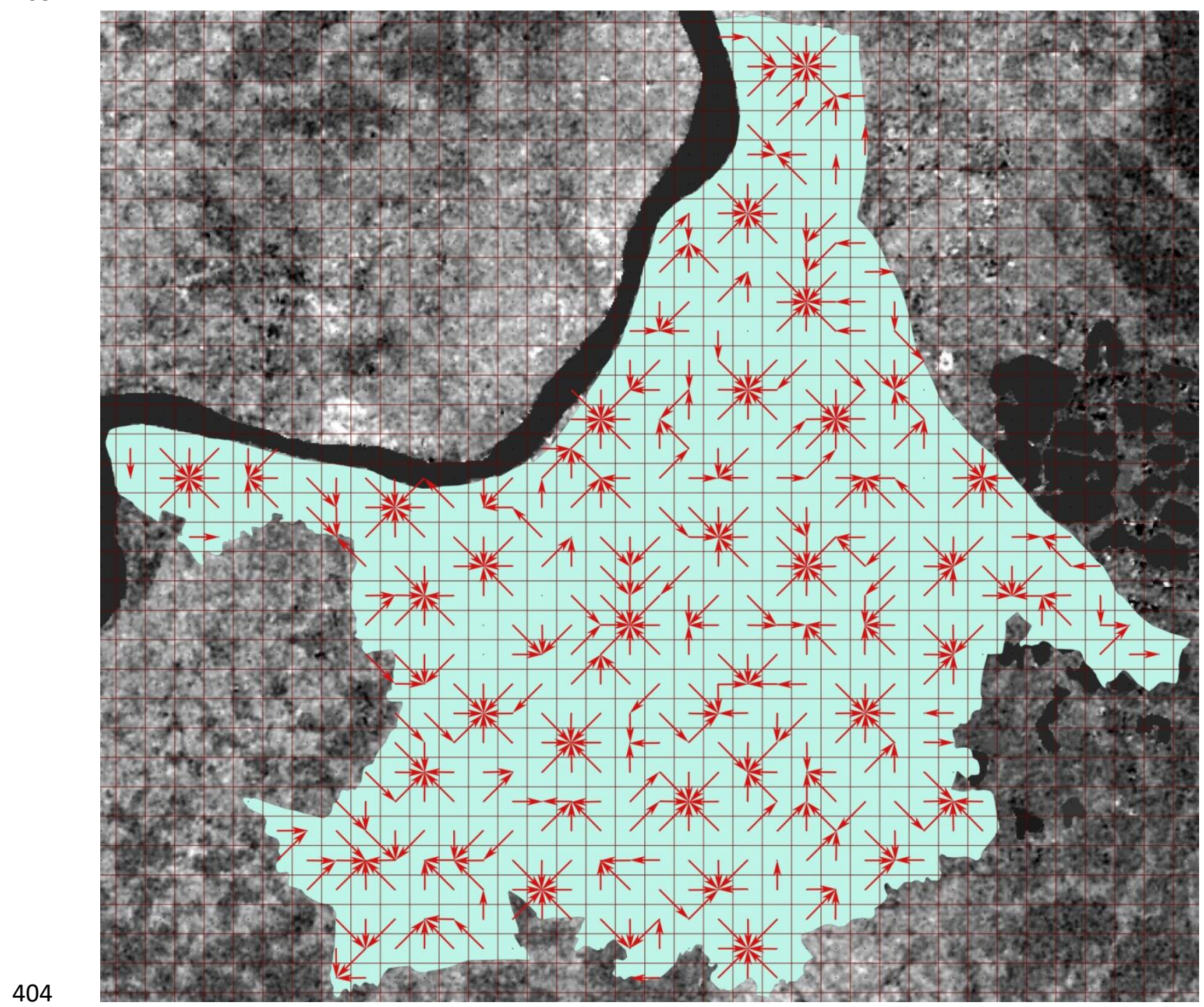

405

Fig. 13. Run-off pattern using FD4O method.

406

407

\section{Results Analysis}

408

409

410

411

412

413

414

\subsection{Waterlogging areas in Kolkata}

Before going to analysis of the flow pattern obtained using all four methods, the actual scenario of the waterlogging areas of Kolkata is depicted below in Fig. 14. Kolkata is infamous for the waterlogging problem. A large part of the city's low areas is deluged for a considerable period disturbing city life to a large extent. It can be seen from the water logging 
417

418

419

420

map of Kolkata that most waterlogging areas are as follows neglecting few water pockets scattered elsewhere.

\begin{tabular}{llllll}
$\circ$ & Maniktala & $\circ$ & Bantala & $\circ$ & Jadavpur \\
$\circ$ & Sealdaha & $\circ$ & Alipore & $\circ$ & Kudghat \\
$\circ$ & Park Street & $\circ$ & New Alipore & $\circ$ & Behala \\
$\circ$ & Ballygaunj & & & & \\
\hline
\end{tabular}

There are also some famous streets which are having a tendency to being waterlogged after a short rainfall. These are,

\begin{tabular}{llll}
\hline$\circ$ & Amherst Street & $\circ$ & Part of BB gangly street \\
$\circ$ & Lansdown Road. & $\circ$ & Part of MG road \\
$\circ$ & CIT road & $\circ$ & Part of CR avenue \\
\hline
\end{tabular}

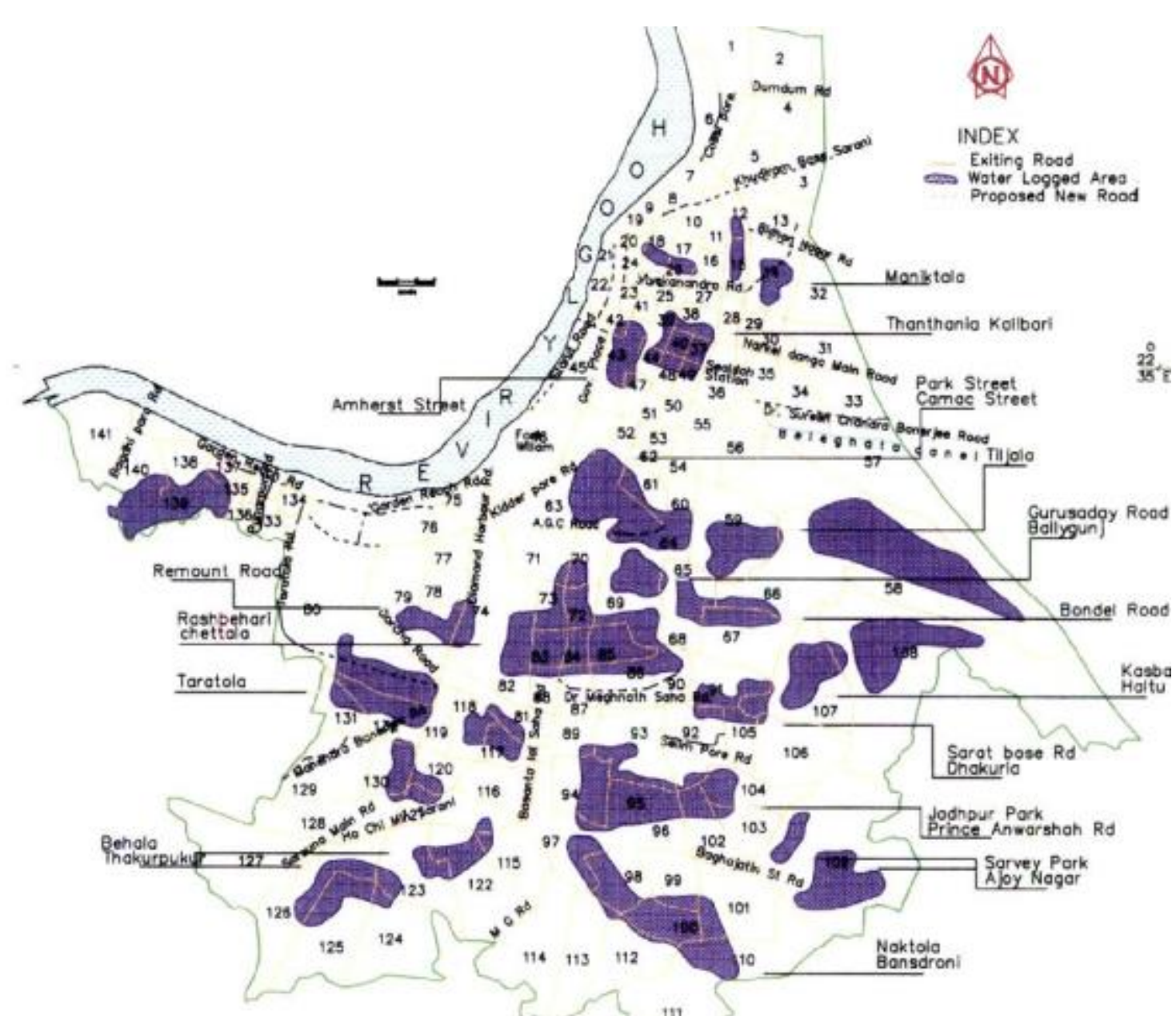

Fig. 14. Waterlogged map of Kolkata (Mukhopadhyay, 2004)

\subsection{Analysis}

The flow pattern from all these methods using $600 \mathrm{~m} \times 600 \mathrm{~m}$ grids is further analyzed to determine the flow accumulation pattern in Kolkata. To find out the same, the following principle is followed. First, all the points in the grid system are given proper nomenclature. In the next picture (Fig. 15) a, b, c...aa, bb, etc. are denoted as rows and 1, 23... are progressive numbers along each row for $600 \mathrm{~m} \times 600 \mathrm{~m}$ grid (Fig. 15). Based on the flow direction as 

any cell is determined.

434

435

436

437

438

439

440

441

442

443

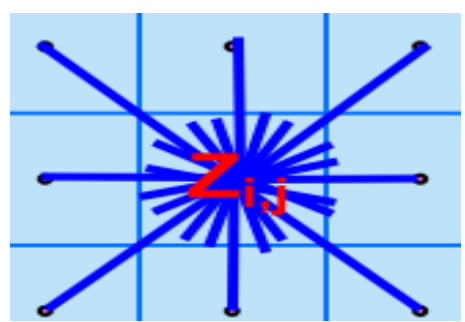

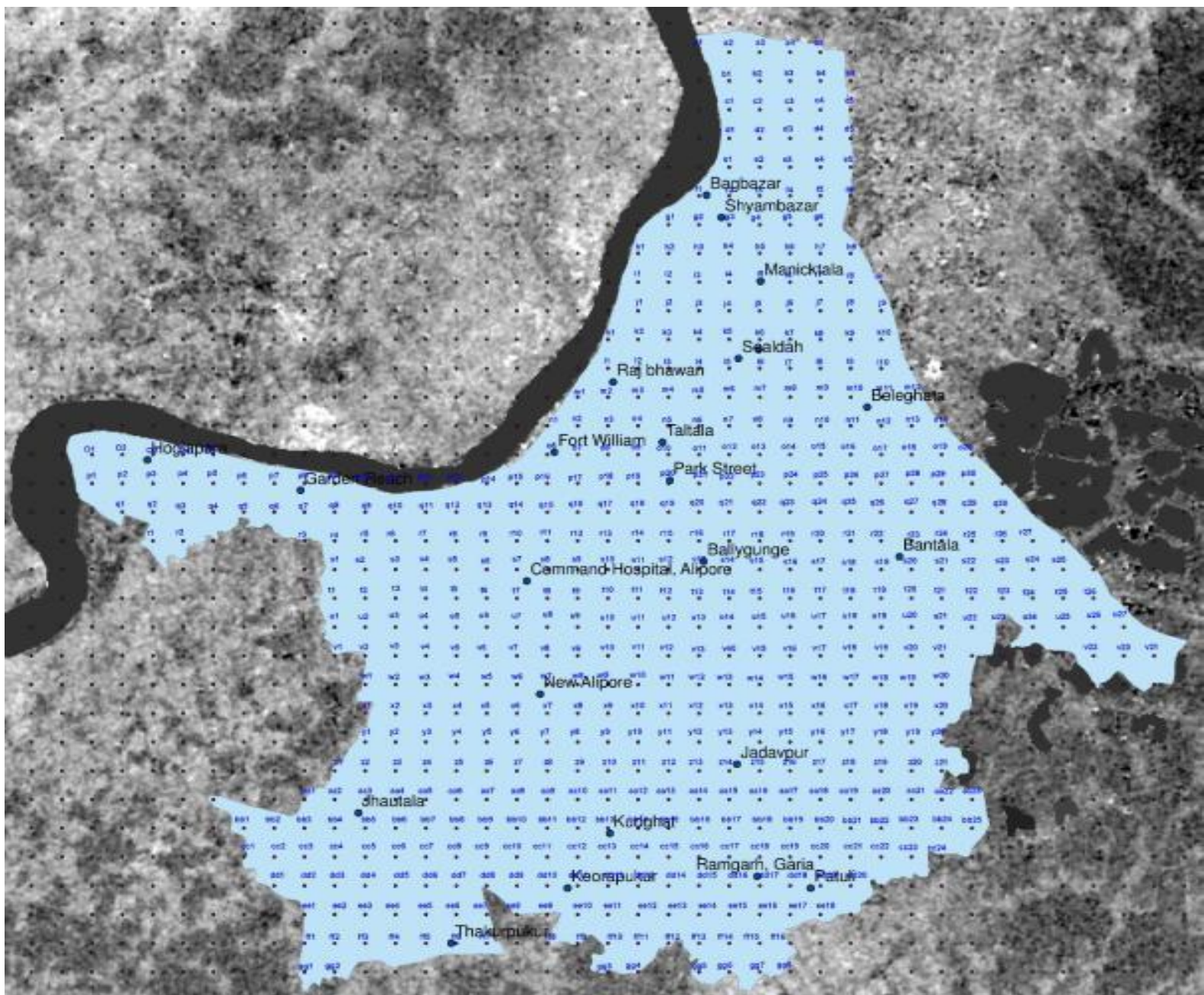

Fig. 16. DEM of Kolkata with the nomenclature.

As an example, in Fig.16(a) flow is coming from nearest all eight (8) cells, then relative flow accumulation potential is described as 8 . If the next any cell to the nearest eight-cell is also contributed to the above particular cell, the same is also added in the overall tally while finding out water logging potential. In Fig.16 (b) flow from surrounding three (3) cells also are contributing the centre cell $z i, j, k$. Thus relative flow accumulation potential of $z i, j, k$ is defined as 11 .

Fig. 16. Flow accumulation Potential of (a) location $z_{i, j, k}$ is 8 and (b) location $z i, j, k$ is 11 .

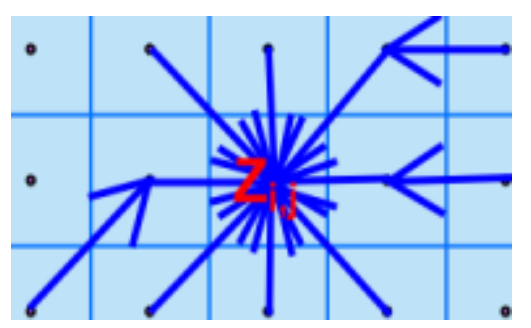


In Table 1, we have identified three types of waterlogging areas, mild, moderate and massive.

447 These names are given according to our postulation that a particular centre cell will be called

448 a waterlogging area depending on how many surrounding cells water enter it. If the number

449 of surrounding cells, from which water is coming towards the centre cell, increases then it

450 implies that the centre cell area is more waterlogged. Here we look only at the massive

451 waterlogged pockets of the study area. Accordingly using all the methods, we have estimated

452 the most waterlogged areas and compared the results with the actual scenario. The flow

453 accumulation potential for all points are thus determined using the above considerations.

454

455 Table 1 Waterlogging potential postulation

\begin{tabular}{|c|c|}
\hline $\begin{array}{c}\text { Type of } \\
\text { waterlogging area }\end{array}$ & Postulation \\
\hline Mild & $\begin{array}{r}\text { If the water is coming towards a centre cell from only 1-2 } \\
\text { numbers of the surrounding cells }\end{array}$ \\
\hline Moderate & $\begin{array}{c}\text { If the water is coming towards a centre cell from 3-5 numbers } \\
\text { of the surrounding cells }\end{array}$ \\
\hline Massive & $\begin{array}{c}\text { If the water is coming towards a centre cell from the 6-8 } \\
\text { numbers of surrounding cells or more }\end{array}$ \\
\hline
\end{tabular}

456

457 After determining flow accumulation potential using all the above methods, we have 458 compared the same with the potential waterlogging area of Kolkata. The main intention is to 459 find out whether the outcome of these methods is matching with the outcome of all methods 460 or not and which method is more accurate. More flow accumulation zones are identified 461 considering run-off is coming from six (6) or more cells. Our assumption in this regard is that

462 it is independent of any rainfall. It is also not taking any account of the simultaneous 463 underground drainage pumping system effect. The flow accumulation areas as obtained from 464 all four methods are shown in Figs. 17-20 and circled in red. Here all the areas like 465 Maniktala, Sealdaha, Alipore, etc are demarcated as points. These points are randomly 466 chosen within the given area.

467 


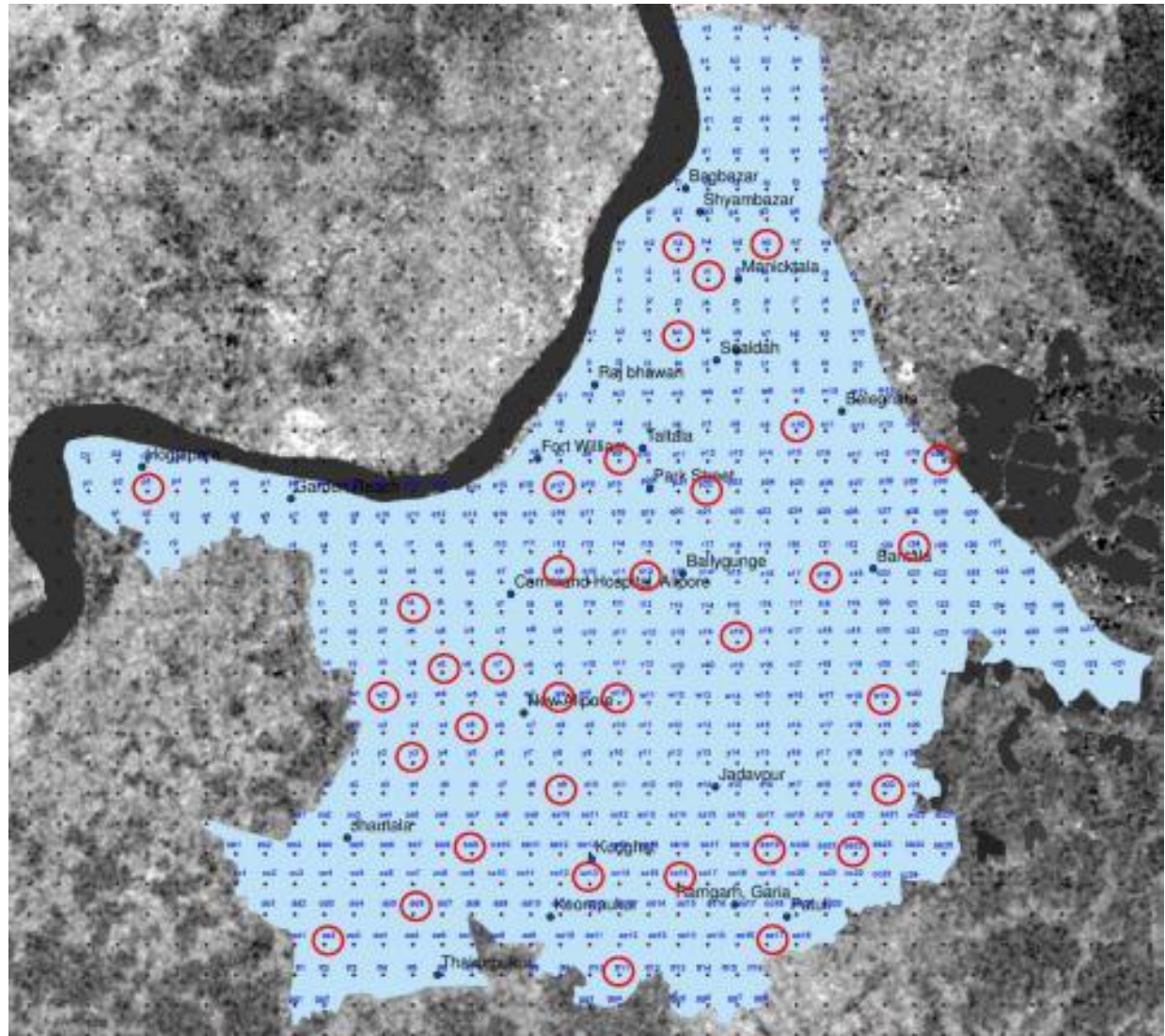

Fig. 17. Most waterlogged areas identified using the D8A method.

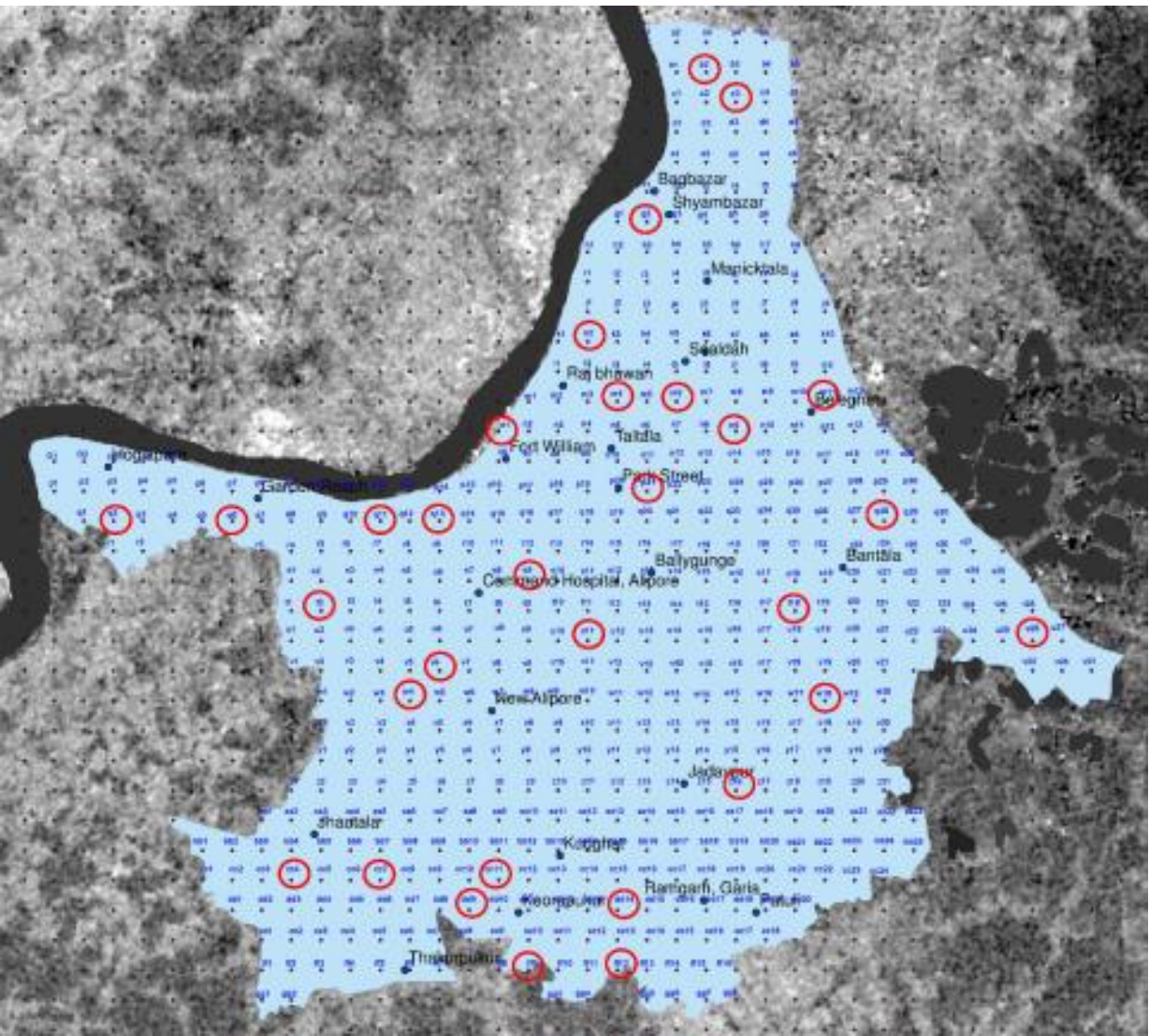

Fig. 18. Most waterlogged areas identified using the FD2O method. 


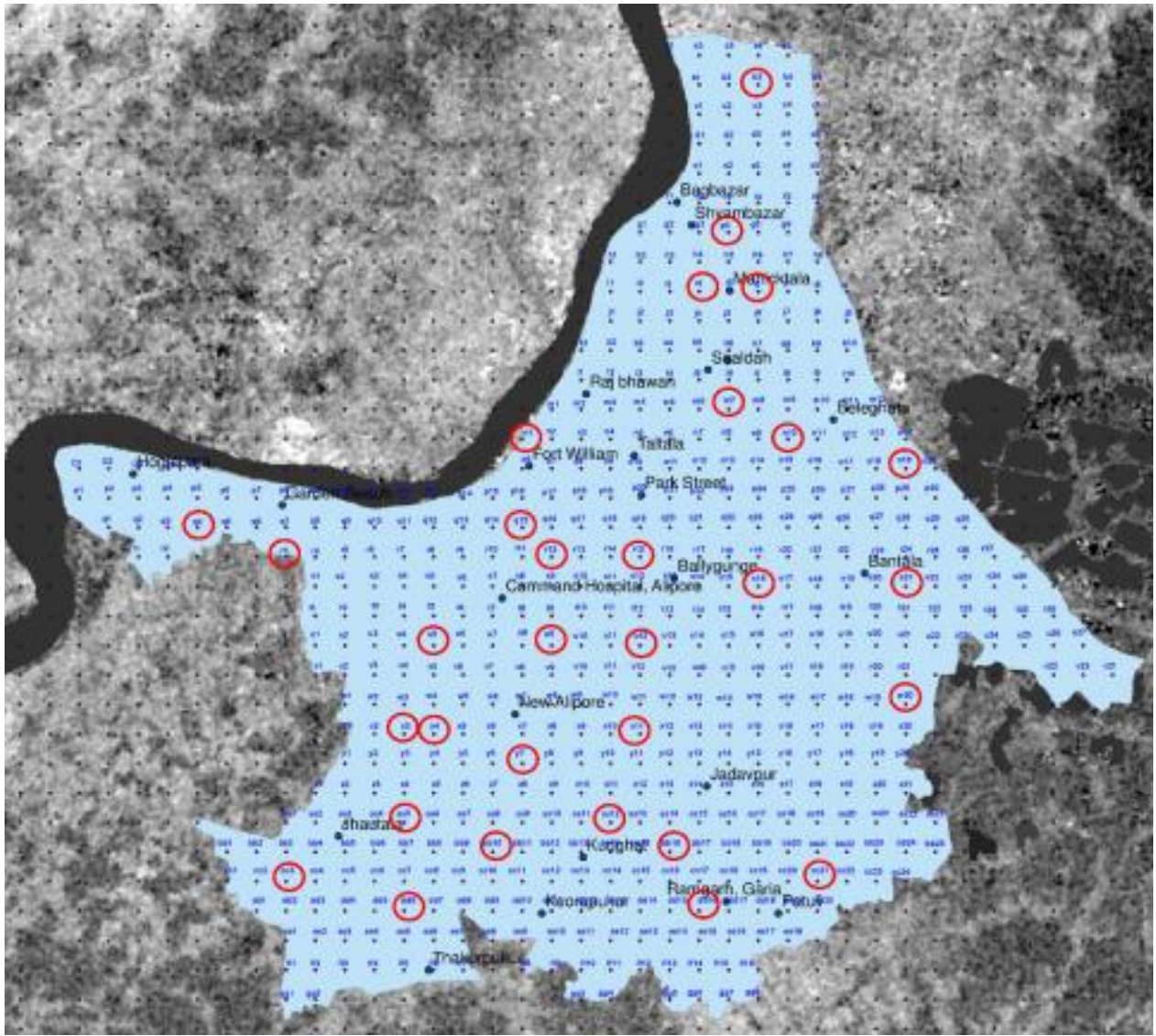

Fig. 19. Most waterlogged areas identified using the FD3O method.

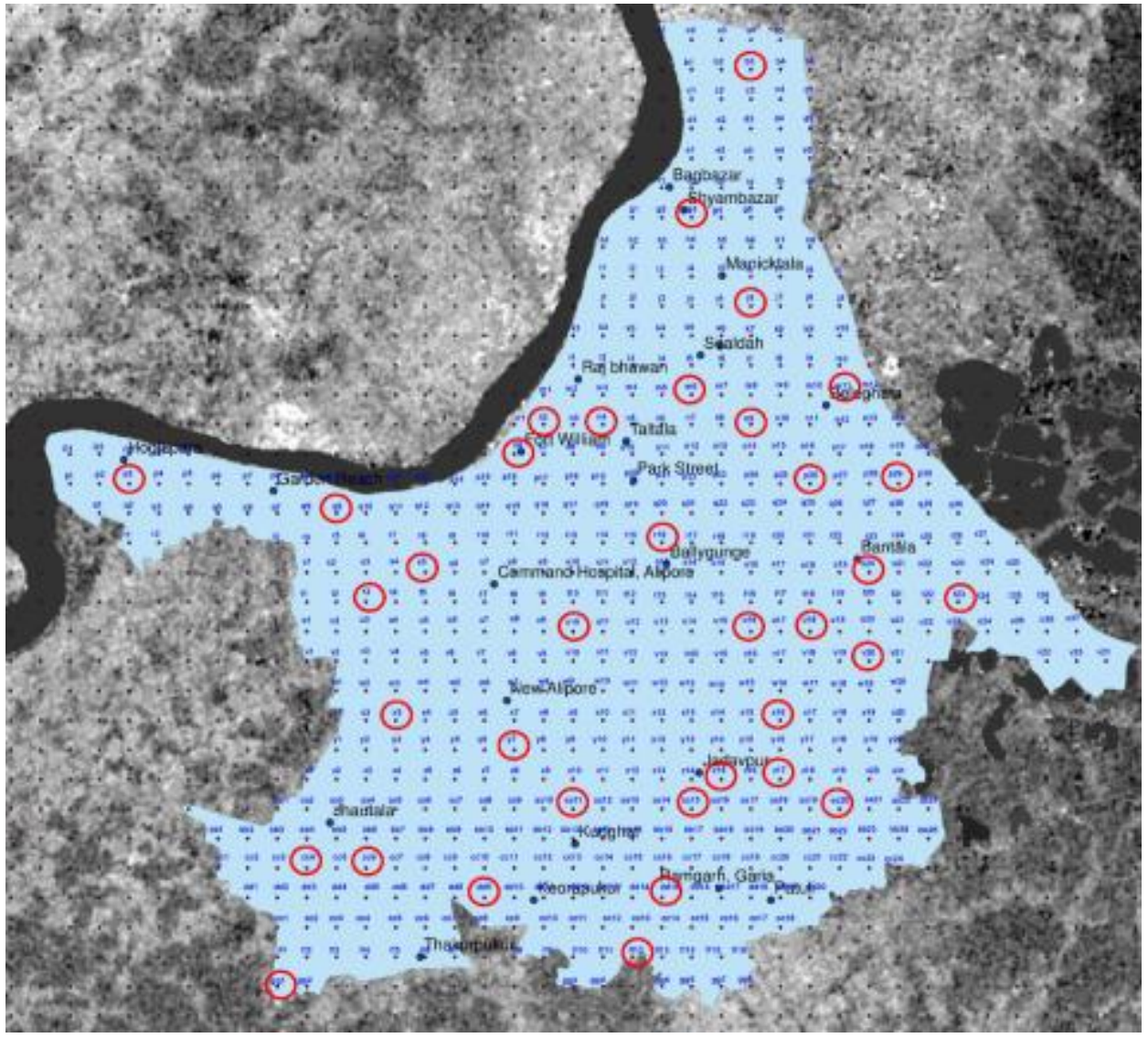

Fig. 20. Most waterlogged areas identified using the FD4O method. 
479 Next, the flow accumulation area as evaluated from the above methods is compared with the 480 above water logging map of Kolkata and the following inferences are deduced. It is actually compared whether the flow accumulation area of the left-hand side of Table 2 are matching with the map of Kolkata or not. If it is not matching then approximately, how far it deviates from the actual scenario is also deduced. Nevertheless, if we have considered that run-off is coming from five adjacent cells or less, then the number of waterlogging zones would have increased. Since we are about to find out the most waterlogging area, we are neglecting the potentially smaller waterlogging area.

Table 2 Waterlogging zone of Kolkata: A comparison of all methods

\begin{tabular}{|c|c|c|c|c|}
\hline Area & D8A Method & FD2O Method & FD3O Method & FD4O Method \\
\hline Maniktala & Matching & $\begin{array}{l}\text { The nearest } \\
\text { waterlogging area is } \\
1.2 \mathrm{~km}(=2 \Delta x) \text { away }\end{array}$ & Matching & Matching \\
\hline Sealdaha & $\begin{array}{l}\text { The nearest } \\
\text { waterlogging area is } \\
0.6 \mathrm{~km}(=\Delta x) \text { away }\end{array}$ & $\begin{array}{l}\text { The nearest } \\
\text { waterlogging area is } \\
0.6 \mathrm{~km}(=\Delta x) \text { away }\end{array}$ & $\begin{array}{l}\text { The nearest } \\
\text { waterlogging area is } \\
0.6 \mathrm{~km}(=\Delta x) \text { away }\end{array}$ & $\begin{array}{l}\text { The nearest } \\
\text { waterlogging area is } \\
0.6 \mathrm{~km}(=\Delta x) \text { away }\end{array}$ \\
\hline $\begin{array}{l}\text { Park } \\
\text { Street }\end{array}$ & Matching & Matching & $\begin{array}{l}\text { The nearest } \\
\text { waterlogging area is } \\
1.2 \mathrm{~km}(=2 \Delta x) \text { away }\end{array}$ & $\begin{array}{l}\text { The nearest } \\
\text { waterlogging area is } \\
1.2 \mathrm{~km}(=2 \Delta x) \text { away }\end{array}$ \\
\hline Ballygaunj & Matching & $\begin{array}{l}\text { The nearest } \\
\text { waterlogging area is } \\
1.2 \mathrm{~km}(=2 \Delta x) \text { away }\end{array}$ & $\begin{array}{l}\text { The nearest } \\
\text { waterlogging area is } \\
0.6 \mathrm{~km}(=\Delta x) \text { away }\end{array}$ & Matching \\
\hline Bantala & $\begin{array}{l}\text { The nearest } \\
\text { waterlogging area is } \\
0.6 \mathrm{~km}(=\Delta x) \text { away }\end{array}$ & $\begin{array}{l}\text { The nearest } \\
\text { waterlogging area is } \\
0.6 \mathrm{~km}(=\Delta x) \text { away }\end{array}$ & Matching & Matching \\
\hline Alipore & $\begin{array}{l}\text { The nearest } \\
\text { waterlogging area is } \\
1.2 \mathrm{~km}(=2 \Delta x) \text { away }\end{array}$ & $\begin{array}{l}\text { The nearest } \\
\text { waterlogging area is } \\
0.6 \mathrm{~km}(=\Delta x) \text { away }\end{array}$ & $\begin{array}{l}\text { The nearest } \\
\text { waterlogging area is } \\
0.6 \mathrm{~km}(=\Delta x) \text { away }\end{array}$ & $\begin{array}{l}\text { The nearest } \\
\text { waterlogging area is } \\
1.2 \mathrm{~km}(=2 \Delta x) \text { away }\end{array}$ \\
\hline $\begin{array}{l}\text { New } \\
\text { Alipore }\end{array}$ & Matching & $\begin{array}{l}\text { The nearest } \\
\text { waterlogging area is } \\
1.2 \mathrm{~km}(=2 \Delta x) \text { away }\end{array}$ & $\begin{array}{l}\text { The nearest } \\
\text { waterlogging area is } \\
0.6 \mathrm{~km}(=\Delta x) \text { away }\end{array}$ & $\begin{array}{l}\text { The nearest } \\
\text { waterlogging area is } \\
0.6 \mathrm{~km}(=\Delta x) \text { away }\end{array}$ \\
\hline Jadavpur & $\begin{array}{l}\text { The nearest } \\
\text { waterlogging area is } \\
1.2 \mathrm{~km}(=2 \Delta x) \text { away }\end{array}$ & $\begin{array}{l}\text { The nearest } \\
\text { waterlogging area is } \\
0.6 \mathrm{~km}(=\Delta x) \text { away }\end{array}$ & $\begin{array}{l}\text { The nearest } \\
\text { waterlogging area is } \\
1.2 \mathrm{~km}(=2 \Delta x) \text { away }\end{array}$ & Matching \\
\hline Kudghat & Matching & $\begin{array}{l}\text { The nearest } \\
\text { waterlogging area is } \\
1.2 \mathrm{~km}(=2 \Delta x) \text { away }\end{array}$ & Matching & Matching \\
\hline Behala & Matching & $\begin{array}{l}\text { The nearest } \\
\text { waterlogging area is } \\
1.2 \mathrm{~km}(=2 \Delta x) \text { away }\end{array}$ & Matching & Matching \\
\hline
\end{tabular}

From the above Table 2, it can be identified that the D8A and FD4O methods are found to be more accurate amongst all methods. 


\subsection{Comparison of gradient values}

494

495

The accuracy of the above methods can also be evaluated by the gradient of the respective points. Random points can be chosen over the DEM for the calculation of gradient points. However, for ease of identification, we have chosen the zones as mentioned in Table 2. The gradient can be calculated by all methods using equation 6 whereas the true gradient value can be calculated from the contour map. The calculated gradient of the selected zones already calculated using the above methods is indicated in Table 3. True gradient magnitudes are determined by hand by depicting a tangent on a contour-line going through the grid point and drawing a perpendicular tangent bisector. The gradient magnitude is computed by dividing the height difference with the perpendicular bisector by the perpendicular bisector length. It is by hand computed and values, as obtained from this method, are taken as the true values. Wherever the contour is not passing through the respective point(s), necessary interpolation is done between two adjacent contour curves. The contour map of Kolkata is indicated below in Fig. 21.

508

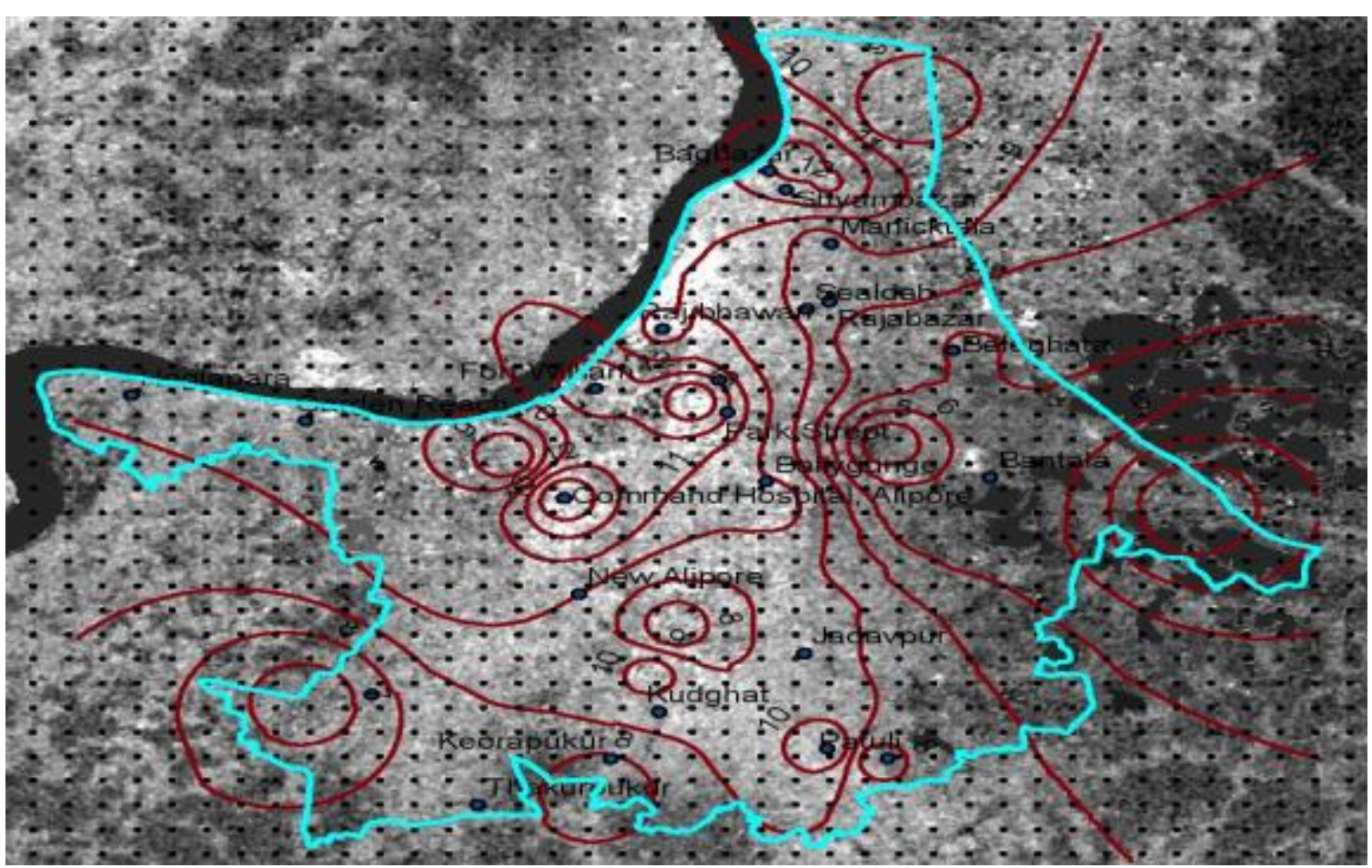

Fig. 21. Ground surface elevation contour map of Kolkata.

The gradient of all the points then calculated using equation 6 as described before and the ratio to the calculated gradient $\left(C_{g}\right)$ and mean gradient values $\left(C_{g m}\right)$ are calculated (Table 3$)$.

(1)

16

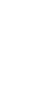


Table 3 Gradient of selected points using all methods.

\begin{tabular}{cccccc}
\hline $\begin{array}{c}\text { Sl. No. } \\
(n)\end{array}$ & $\begin{array}{c}\text { Area } / \\
\text { Location }\end{array}$ & $\begin{array}{c}C_{g} / C_{g m} \\
(\mathrm{D} 8 \text { Model })\end{array}$ & $\begin{array}{c}C_{g} / C_{g m} \\
\text { (Second Order) }\end{array}$ & $\begin{array}{c}C_{g} / C_{g m} \\
\text { (Third Order) }\end{array}$ & $\begin{array}{c}C_{g} / C_{g m} \\
\text { (Fourth Order) }\end{array}$ \\
\hline 1 & Alipore & 0.95 & 2.39 & 2.34 & 1.16 \\
2 & Ballygaunj & -0.49 & 1.15 & 0.60 & 1.76 \\
3 & Bantala & 0.95 & 1.32 & 1.30 & 0.79 \\
4 & Behala & 1.66 & 0.56 & 1.18 & 0.17 \\
5 & Jadavpur & 0.49 & 0.00 & 0.22 & 0.30 \\
6 & Kudghat & 0.72 & 0.56 & 0.58 & 0.59 \\
7 & Maniktala & 0.95 & 0.74 & 0.58 & 0.87 \\
8 & New Alipore & 1.43 & 0.41 & 0.58 & 0.97 \\
9 & Park Street & 2.87 & 1.89 & 2.17 & 2.90 \\
10 & Sealdaha & 0.49 & 0.98 & 0.46 & 0.50 \\
\hline
\end{tabular}

521

522

523

524

525

526

Next, true gradient points are found out, which is the ratio to the difference between the elevation of adjacent two contour lines (sloping downwards) and the difference in distance between the points while calculated by drawing a bisector from the respective points as described above. A sample calculation (based on Fig. 22) is shown below using equation 15.

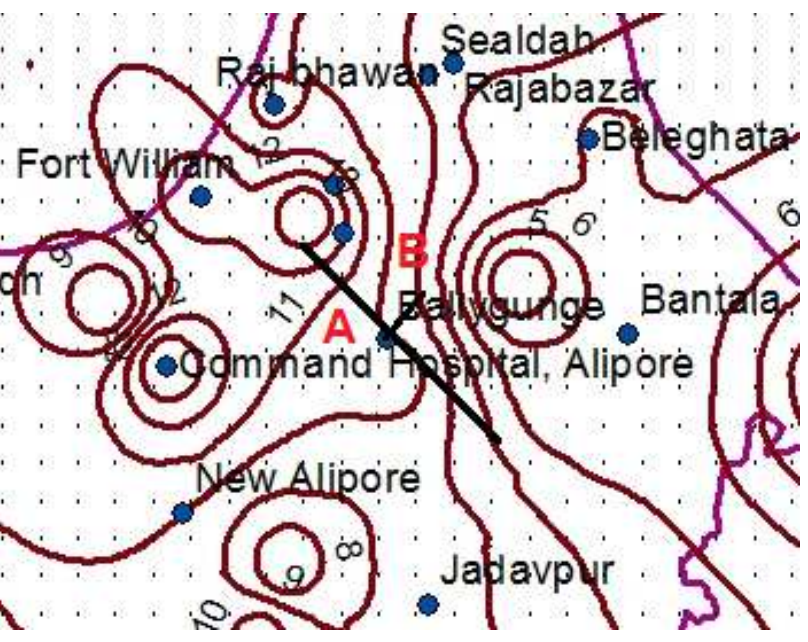

Fig. 22. Sample calculation of true gradient.

Let us assume that we have to measure the gradient value at point A (Ballygaunj). It is passing through the contour line having a value like 10 . So first we need to draw a tangent along the contour line passing through point $\mathrm{A}$. Thereafter perpendicular bisector needs to be drawn at point $A$. The same cuts the next lower contour line (with respect to point $A$ ) at point B. Point B is passing through contour line 9. Thus, the gradient of point A is as follows,

The Gradient at $\mathrm{A}=\frac{\text { Difference between elevations at Point } \mathrm{A} \text { and } \mathrm{B}}{\text { The horizontal distance between } \mathrm{A} \text { and } \mathrm{B}}$

Whenever any point is not passing through a contour line, necessary interpolation has been done to find out the elevation of this point. 


\subsection{Comparison of true and calculated gradients}

Values of true and calculated gradients as obtained based on the above are graphically compared and shown below in Fig. 23. The values of the true gradient $\left(T_{g}\right)$ and calculated gradient $\left(C_{g}\right)$ are normalized by their mean values $T_{g m}$ and $C_{g m}$, respectively.

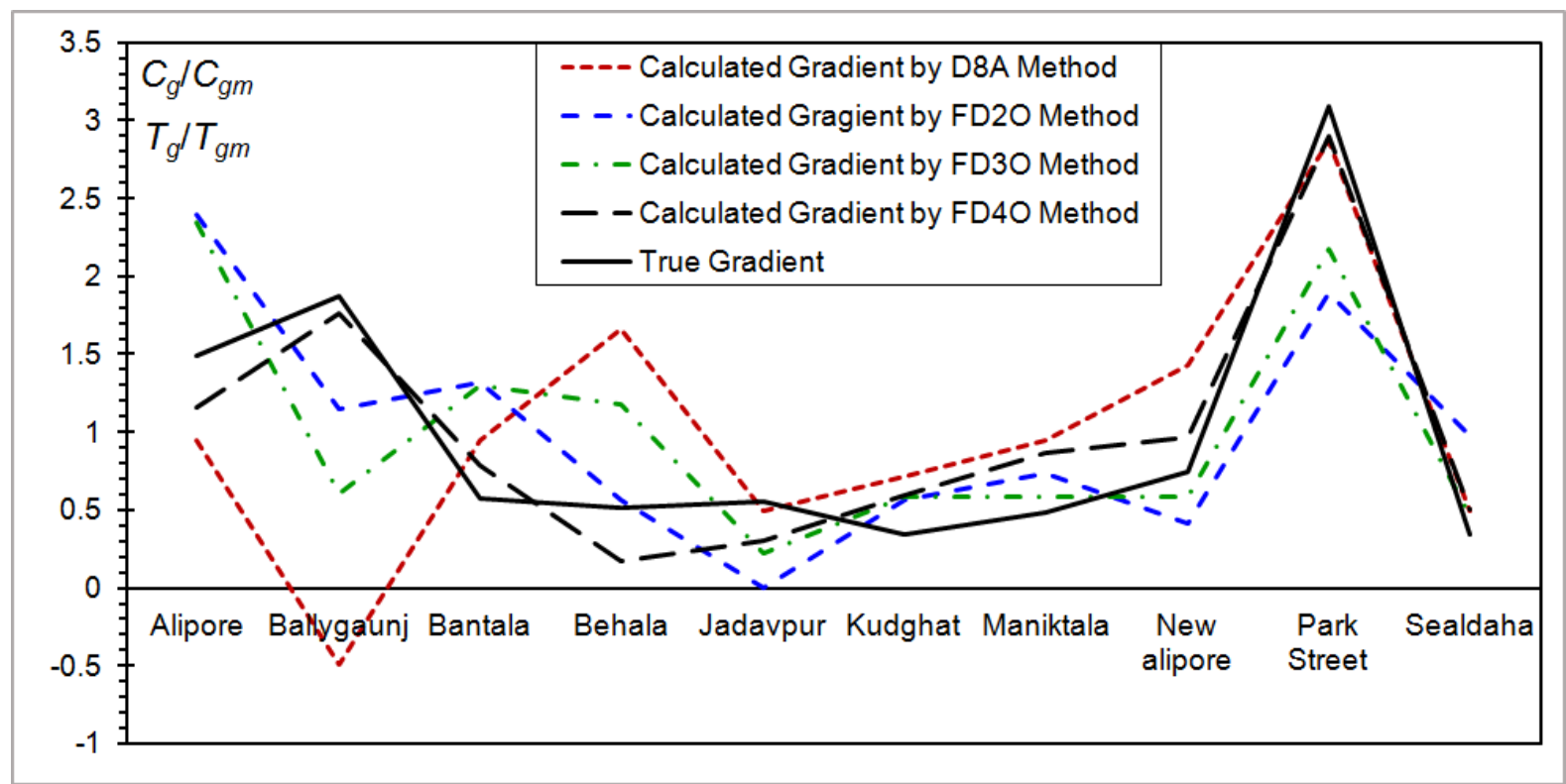

Fig. 23. Comparison of the normalized true and calculated gradients using the D8A, FD2O, FD3O, and FD4O methods.

It can be seen that there are some errors in the magnitude of 0.01 between true and calculated gradient. The same can be seen in the following bar chart (Fig. 24) for all the methods.

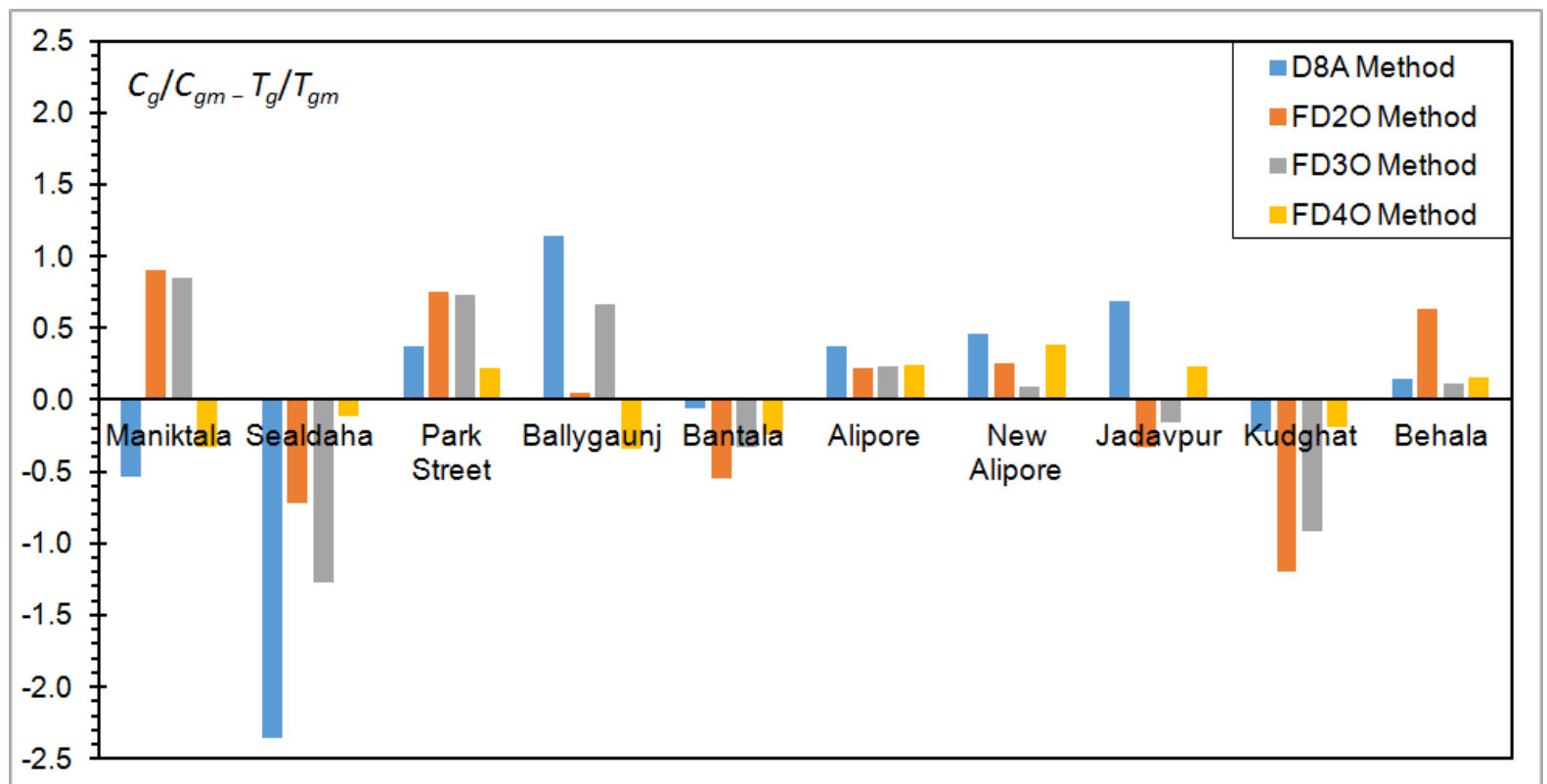

Fig. 24. The difference between normalized true and calculated gradients using the D8A, FD2O, FD3O, and FD4O methods. 
The true gradient is calculated manually and a $600 \mathrm{~m} \times 600 \mathrm{~m}$ grid is used. Hence error between these values is quite evident and cannot be ruled off. However, if we have considered in a particular zone using $100 \mathrm{~m} \times 100 \mathrm{~m}$ cell or even smaller, the chances of error of these values can be further minimized.

563

\subsection{Spearman rank coefficient}

565

It is important to mention the monotonic function before describing Spearman's correlation. A monotonic function is one that either never increases or never decreases as its independent variable increases. The monotonic function can be three types.

- Increasing monotonically: as the $x$ variable increases the variable $y$ never decreases.

570

- Decreasing monotonically: as the $x$ variable increases the variable $y$ never increases.

o Not monotonic: as the variable $x$ increases the variable $y$ sometimes decreases and sometimes increases.

Spearman's rank correlation coefficient is a statistical method to determine the strength of a monotonic relationship between paired data. It is denoted normally by $r_{s p}$. The value of $r_{s p}$ normally falls as shown below in equation 17 .

$$
-1 \leq r_{s p} \leq+1
$$

577 The strength of the Spearman correlation between the calculated and true gradient 578 values can be found out as follows,

$579 \quad 0 \quad 0.00 \leq r_{s p} \leq 0.19$ implies - "very weak" correlation;

$580 \bigcirc 0.20 \leq r_{s p} \leq 0.39$ implies - "weak" correlation;

$581 \quad 0 \quad 0.40 \leq r_{s p} \leq 0.59$ implies - "moderate" correlation;

$582 \circ 0.60 \leq r_{s p} \leq 0.79$ implies - "strong" correlation;

$583 \circ 0.80 \leq r_{s p} \leq 1.00$ implies - "very strong" correlation.

584 Spearman correlation coefficient can be defined as follows.

$$
r_{s}=\frac{1-6 \sum d_{i}^{2}}{n\left(n^{2}-1\right)}
$$

586

587

588

589

590

591

592

593

where $n=$ number of points for the variable in question.

To find out the relation between the locations wise true and calculated gradients in each method, the Spearman correlation coefficient has been calculated.

Table 4 addresses the Spearman coefficient evaluation using the D8A method. Here, the Spearman coefficient $r_{\mathrm{s}}$ is found 0.369 and thereby the relationship between the true and calculated gradient is found weak.

Table 4 Spearman coefficient using the D8A method.

\begin{tabular}{ccccccc}
\hline Location & $C_{g} / C_{g m}$ & $T_{g} / T_{g m}$ & $x_{i}$ & $y_{i}$ & $d_{i}=x_{i}-y_{i}$ & $d_{i}{ }^{2}$ \\
\hline Ballygaunj & -0.49 & 1.87 & 1 & 9 & -8 & 64 \\
Sealdaha & 0.49 & 0.34 & 2 & 1 & 1 & 1 \\
Jadavpur & 0.49 & 0.55 & 3 & 5 & -2 & 4 \\
\hline
\end{tabular}




\begin{tabular}{ccccccc}
\hline Kudghat & 0.72 & 0.34 & 4 & 2 & 2 & 4 \\
Maniktala & 0.95 & 0.49 & 5 & 3 & 2 & 4 \\
Bantala & 0.95 & 0.57 & 6 & 6 & 0 & 0 \\
Alipore & 0.95 & 1.49 & 7 & 8 & -1 & 1 \\
New Alipore & 1.43 & 0.74 & 8 & 7 & 1 & 1 \\
Behala & 1.66 & 0.51 & 9 & 4 & 5 & 25 \\
Park Street & 2.87 & 3.09 & 10 & 10 & 0 & 0 \\
\hline
\end{tabular}

594

595

596

597

598

599

Table 5 illustrates the Spearman coefficient evaluation using the FD2O method. Here, the Spearman coefficient $r_{s p}$ is found 0.612 and thereby the relationship between the true and calculated gradient is found strong.

Table 5 Spearman coefficient using the FD2O method.

\begin{tabular}{ccccccc}
\hline Location & $C_{g} / C_{g m}$ & $T_{g} / T_{g m}$ & $x_{i}$ & $y_{i}$ & $d_{i}=x_{i}-y_{i}$ & $d_{i}{ }^{2}$ \\
\hline Jadavpur & 0.00 & 0.55 & 1 & 5 & -4 & 16 \\
New Alipore & 0.41 & 0.74 & 2 & 7 & -5 & 25 \\
Kudghat & 0.56 & 0.34 & 3 & 2 & 1 & 1 \\
Behala & 0.56 & 0.51 & 4 & 4 & 0 & 0 \\
Maniktala & 0.74 & 0.49 & 5 & 3 & 2 & 4 \\
Sealdaha & 0.98 & 0.34 & 6 & 1 & 5 & 25 \\
Ballygaunj & 1.15 & 1.87 & 9 & 9 & 0 & 0 \\
Bantala & 1.32 & 0.57 & 8 & 6 & 2 & 4 \\
Park Street & 1.89 & 3.09 & 9 & 10 & -1 & 1 \\
Alipore & 2.39 & 1.49 & 10 & 8 & 2 & 4 \\
\hline
\end{tabular}

600

601

Table 6 depicts the Spearman coefficient evaluation using the FD3O method. In this method,

602 the Spearman coefficient $r_{s p}$ is found 0.624 and thereby the relationship between the true and

603 calculated gradient is found strong.

604

605

Table 6 Spearman coefficient evaluation using the FD3O method.

\begin{tabular}{ccccccc}
\hline Location & $C_{g} / C_{g m}$ & $T_{g} / T_{g m}$ & $x_{i}$ & $y_{i}$ & $d_{i}=x_{i}-y_{i}$ & $d_{i}^{2}$ \\
\hline Jadavpur & 0.22 & 0.55 & 1 & 5 & -4 & 16 \\
Sealdaha & 0.46 & 0.34 & 2 & 1 & 1 & 1 \\
Maniktala & 0.58 & 0.49 & 3 & 3 & 0 & 0 \\
New alipore & 0.58 & 0.74 & 4 & 7 & -3 & 9 \\
Kudghat & 0.58 & 0.34 & 5 & 2 & 3 & 9 \\
Ballygaunj & 0.60 & 1.87 & 6 & 9 & -3 & 9 \\
Behala & 1.18 & 0.51 & 7 & 4 & 3 & 9 \\
Bantala & 1.30 & 0.57 & 8 & 6 & 2 & 4 \\
Park Street & 2.17 & 3.09 & 9 & 10 & -1 & 1 \\
Alipore & 2.34 & 1.49 & 10 & 8 & 2 & 4 \\
\hline
\end{tabular}

606 
612

613

614

615

616

617

618

619

620

621

622

623

624

625

626

627

628

629

630

Table 7 highlights the Spearman coefficient evaluation using the FD4O method. Here, the Spearman coefficient $r_{s p}$ is found 0.7818 and thereby the relationship between the true and calculated gradient is found nearly very strong.

Table 7 Spearman coefficient evaluation using the FD4O method.

\begin{tabular}{ccccccc}
\hline Location & $C_{g} / C_{g m}$ & $T_{g} / T_{g m}$ & $x_{i}$ & $y_{i}$ & $d_{i}=x_{i}-y_{i}$ & $d_{i}{ }^{2}$ \\
\hline Behala & 0.17 & 0.51 & 1 & 4 & -3 & 9 \\
Jadavpur & 0.30 & 0.55 & 2 & 5 & -3 & 9 \\
Sealdaha & 0.50 & 0.34 & 3 & 1 & 2 & 4 \\
Kudghat & 0.59 & 0.34 & 4 & 2 & 2 & 4 \\
Bantala & 0.79 & 0.57 & 5 & 6 & -1 & 1 \\
Maniktala & 0.87 & 0.49 & 6 & 3 & 3 & 9 \\
New Alipore & 0.97 & 0.74 & 7 & 7 & 0 & 0 \\
Alipore & 1.16 & 1.49 & 8 & 8 & 0 & 0 \\
Ballygaunj & 1.76 & 1.87 & 9 & 9 & 0 & 0 \\
Park Street & 2.90 & 3.09 & 10 & 10 & 0 & 0 \\
\hline
\end{tabular}

Therefore, from Tables 4-7, it is clear that the FD4O method is the most accurate amongst all the methods considered here.

The next statistical analysis is carried out to establish the fact of whether the FD4O method is more accurate or not. Here we have used root-mean-square-error (RMSE), relative root-mean-square-error (RRMSE), G test, and mean difference method between true and calculated gradient values.

Based on the above equations 18-21, RMSE, RRMSE, G test and mean differences are calculated and indicated in Table 8.

The RMSE value was found minimum for the FD4O method. The RRMSE and mean difference values are lowest for the D8A and FD4O methods, respectively. Hence it can be furnished that the error in D8A and FD4O methods is less and the calculated gradient value has a tendency to coincide with the true gradient value. 
Table 8 RMSE, RRMSE, G test, Mean difference values of all methods

\begin{tabular}{ccccc}
\hline Method & RMSE & RRMSE & Mean difference & G Test \\
\hline D8A & 0.003139 & 0.73 & 0.000577 & 0.00410 \\
FD2O & 0.003105 & 1.06 & 0.001697 & 0.00622 \\
FD3O & 0.002734 & 0.79 & 0.001237 & 0.00440 \\
FD4O & 0.001619 & 0.55 & 0.001127 & 0.00309 \\
\hline
\end{tabular}

632

633

634

635

636

637

638

639

640

641

642

643

644

645

646

647

648

649

650

651

652

653

654

655

656

657

658

659

660

661

662

663

664

665

666

667

668

The RRMSE is more sensitive for estimating gradient errors for pain locations, as large estimated gradient errors in shallow slopes will provide a greater effect on indicator value than equivalent gradient errors for areas with steeper slopes (Warren et al., 2004). Here the least RRMSE is observed when applying the FD4O method. It agrees with the observation of Warren et al. (2004) and confirms that the FD4O method is the best in estimating the gradient and slopes of plain areas. From the observed RMSE and $G$ test values, it is not possible to correlate which method is superior. According to the $95 \%$ Confidence intervals test, the D8A and FD4O methods have considerably lower gradient estimation errors than the FD2O and FD3O methods.

For determining the water logging potential in a smaller area, the grid can be considered $100 \mathrm{~m} \times 100 \mathrm{~m}$ or even less so that the chances of any error can be further reduced. Also for a bigger plain surface like Kolkata, a better result could be obtained if we can focus on any particular area and then study the water logging spots road wise and validate the same from actual data. The waterlogging area of the deltaic city Kolkata depends on its various drainage conditions like details of the drainage pumping station, condition and size of drainage pipe and channel, contribution of drainage flow from the surrounding area, etc. These other conditions reduced some percentage of accuracy of all the four methods applied herein. However, these methods can be applied to rural plain regions having an area of $200 \mathrm{sq} \mathrm{km}$ wherein a proper drainage system not exists, and results can be analyzed with a high accuracy accordingly.

As a further scope of the study, using multi linear models using regression can be reviewed for estimation of the gradient of a plain surface. Also for a large plain surface area (area in the tune of $500 \mathrm{sq} . \mathrm{km}$ ), it is possible to check whether a sufficient accuracy level can be obtained from the D8A method or FD4O method or not using $600 \mathrm{~m} \times 600 \mathrm{~m}$ grid. For calculation of the gradient point, it is seen that as the grid shortens, calculated gradient value approaches towards true gradient value irrespective of any methods. This deduction can be further cross-checked for a smaller zone and the strength of the Spearman coefficient between these two variables can be checked. An alternative Kendall tau coefficient can be obtained to check the relationship of these variables as was also done on a hilly surface by Skidmore (1989).

\section{Conclusions}

It can be concluded that the D8A method (D8 algorithm) and the FD4O method (finite difference technique of fourth order) are mostly correct with comparison to other methods like the FD2O method (finite difference technique of second order) and FD3O method (finite 
difference technique of third order) while determining the flow accumulation potential of a plain surface. The flow accumulation zones of a plain surface region, here deltaic city Kolkata, as derived from the D8A method and the FD4O method are matching the actual flow accumulation area and waterlogging area of Kolkata. Hence, we can therefore conclude that the D8A method and FD4O methods are best suitable while determining water logging potential and flow pattern on a plain surface. Between methods FD2O and FD3O, FD3O happens to be more accurate than the FD2O method. For such comparative analysis, the Spearman rank coefficient method is proven to be the most appropriate compared to other statistical methods like RMSE, RRMSE, G test, and mean difference method.

As the accuracy level is increased from second-order to fourth-order finitedifference, the strength of the variables (i.e. true and calculated gradients) becomes stronger and stronger. For a hilly forest region, there is hardly any difference in the value of the Spearman coefficient between methods like the D8A and FD3O methods. So as the error in the finite difference model decreases, the strength of variables becomes more and more prominent which also points to the fact that if we go for the fourth or higherorder finite-difference model gradient can be more accurately calculated and more prominently flow accumulation area or the waterlogging area of a plain surface can be determined which is in line with our earlier deduction. Nevertheless, the accuracy level will be further increased if we go for smaller size grids. In another way, the fourth order finite-difference model can be used to get a reasonable accuracy to determine the flow accumulation potential of plain surface (area in the tune of $200 \mathrm{sq} \mathrm{km}$ ). However, if a smaller plain surface area is chosen with a smaller grid size, the accuracy level will definitely be increased. Similarly, for a large plain surface area (area in the tune of 500 sq $\mathrm{km}$ or more) fourth-order finite-difference (FD4O) method or D8 algorithm (D8A) method with a higher accuracy level can be successfully used.

\section{Declarations}

The authors have no relevant financial or non-financial interests to disclose. The authors have no conflicts of interest to declare that are relevant to the content of this article.

\section{References}

Anderson JDJ (1995) Computational Fluid Dynamics - The Basics with Applications. International Editions, Schaum Division, McGraw-Hill Inc., New York

Ashraf MI, Zhao Z, Bourque CPA, Meng F (2011) GIS-evaluation of two slope-calculation methods regarding their suitability in slope analysis using high-precision LiDAR digital elevation models. Hydrol Process 26(8):1119-1133. https://doi.org/10.1002/hyp.8195

Banerjee S (2018) An Analysis of Urban Flooding Scenario in the City of Kolkata, West Bengal. Int J Innov Knowl Concept 6(5):1-9. https://doi.org/11.25835/IJIK-24 
Beasely DB, Huggins LF, Monke EJ (1980) A model for watershed planning. Trans Am Soc Agric Eng 23(4):938-944. https://doi.org/10.13031/2013.34692

Beven KJ, Kirkby MJ (1979) A physically based, variable contributing area model of basin hydrology. Hydrol Sci Bull 24(1):43-69. https://doi.org/10.1080/02626667909491834

Bolstad PV, Stowe T (1994) An Evaluation of DEM Accuracy: Elevation, Slope, and Aspect. Photogramm Eng Remote Sens 60(11):1327-1332

Chavda DB, Makwana JJ, Parmar HV, Kunapara AN, Parajapati GV (2016) Estimation of Runoff for Ozat Catchment using RS and GIS based SCS-CN method. Curr World Environ 11(1):212-217. http://dx.doi.org/10.12944/CWE.11.1.26

Cabral MCC, Burges SJ (1994) Digital Elevation Model Networks (DEMON): A model of flow over hillslopes for computation of contributing and dispersal areas. Water Resour Res 30(6):1681-1692. https://doi.org/10.1029/93WR03512

Das S, Patel PP, Sengupta S (2016) Evaluation of different digital elevation models for analyzing drainage morphometric parameters in a mountainous terrain: a case study of the Supin-Upper Tons Basin, Indian Himalayas. SpringerPlus 5:1544. https://doi.org/10.1186/s40064-016-3207-0

Dasgupta S, Roy S, Sarraf M (2012) Urban Flooding in a Changing Climate: Case Study of Kolkata, India. Asian-Afr J Econ Econometric 12(1):135-158.

Fairfield J, Leymarie P (1991) Drainage networks from grid elevation models. Water Resour Res 27(5):709-717. https://doi.org/10.1029/90WR02658

Fortin JP, Turcotte R, Massicotte S, Moussa R, Fitzback J, Villeneuve JP (2001) A distributed watershed model compatible with remote sensing and GIS Data, I: Description of model. J Hydrol Eng 6(2):91-99. https://doi.org/.10.1061/(ASCE)1084-0699(2001)6:2(91)

Gayathri, C. \& Jayalakshmi, S. (2018) Estimation of Surface Runoff Using Remote Sensing and GIS Techniques for Cheyyar Sub Basin. Int J Eng Res Tech 6(7):1-5.

Graham A, Coops NC, Wilcox M, Plowright A (2018) Evaluation of Ground Surface Models Derived from Unmanned Aerial Systems with Digital Aerial Photogrammetry in a Disturbed Conifer Forest. Remote Sens 11(1):84. https://doi.org/10.3390/rs11010084

Grey V, Livesley SJ, Fletcher TD, Szota C (2018) Establishing street trees in stormwater control measures can double tree growth when extended waterlogging is avoided. Landsc Urb Plan 178:122-129. https://doi.org/10.1016/j.landurbplan.2018.06.002

Guo-an T, Strobl J, Gong J, Zhao M, Chen Z (2001) Evaluation on the accuracy of digital elevation models. J Geogr Sci 11(2):209-216. https://doi.org/10.1007/BF02888692

John B, Das S (2020) Identification of risk zone area of declining piezometric level in the urbanized regions around the City of Kolkata based on ground investigation and GIS techniques. Groundw Sustain Dev 11:100354. https://doi.org/10.1016/j.gsd.2020.100354

John B, Das S, Das R (2020) Effect of changing land use scenario in Kolkata Metropolitan on the variation in volume of runoff using multi-temporal satellite images. J Indian Chem Soc 97(4):555-562

Kok K, Sidek LM, Jung K, Kim J (2018) Analysis of Runoff Aggregation Structures with Different Flow Direction Methods under the Framework of Power Law Distribution. Water Resour Manag 32:4607-4623. https://doi.org/10.1007/s11269-018-2074-6 
Kumar PS, Praveen TV, Prasad MA (2016) Rainfall-Runoff Modelling using Modified NRCS-CN, RS and GIS -A Case Study. Int J Eng Res Appl 6(3):54-58

Martz LW, Garbrecht J (1992) Numerical definition of drainage network and subcatchment areas from Digital Elevation Models. Computer Geosci 18(6):747-761. https://doi.org/10.1016/0098-3004(92)90007-E

Mukhopadhyay A (2004) Geomorphology of Kolkata municipal corporation KMC its impact on urban functions. Ph.D. Thesis, Department of Geography, University of Calcutta, India. http://hdl.handle.net/10603/159507

O'Callaghan J, Mark D (1984) The extraction of drainage networks from digital elevation data. Computer Vis Gr Imag Process 28(3):323-344. https://doi.org/10.1016/S0734$189 \mathrm{X}(84) 80011-0$

Paul A (2009) Assessment of waterlogging in C M C and its social impact. Ph.D. Thesis, Department of Geography, University of Calcutta, India. http://hdl.handle.net/10603/154829

Pike AS (2006) Application of digital terrain analysis to estimate hydrological variables in the Luquillo Mountains of Puerto Rico. Climate Variability and ChangeHydrological Impacts (Proceedings of the Fifth FRIEND World Conference held at Havana, Cuba, November 2006), pp. 81-86

Quinn P, Beven KJ, Chevalier P, Planchon O (1991) The prediction of hillslope flow paths for distributed hydrological modelling using digital terrain models. Hydrol Process 5(1):59-79. https://doi.org/10.1002/hyp.3360050106

Rana VK, Suryanarayana TMV (2020) GIS-based multi criteria decision making method to identify potential runoff storage zones within watershed. Ann GIS 26(2):149-168. https://doi.org/10.1080/19475683.2020.1733083

Rhind DW (2013) Automated Contouring-an Empirical Evaluation of Some Differing Techniques. Cartogr J 8(2):145-158. https://doi.org/10.1179/00087041.8.2.p145

Roy R, Dhali MK (2016) Seasonal Water logging Problem In A Mega City: A Study of Kolkata, India. J Res Humanit Soc Sci 4(4):01-09

Sar N, Chatterjee S, Adhikari MD (2015) Integrated remote sensing and GIS based spatial modelling through analytical hierarchy process (AHP) for water logging hazard, vulnerability and risk assessment in Keleghai river basin, India. Model Earth Syst Environ 1: 31. https://doi.org/10.1007/s40808-015-0039-9

Satheeshkumar S, Venkateswaran S, Kannan R (2017) Rainfall-runoff estimation using SCS-CN and GIS approach in the Pappiredipatti watershed of the Vaniyar sub basin, South India. Model Earth Syst Environ 3:24. https://doi.org/10.1007/s40808-0170301-4

Skidmore AK (1989) A comparison of techniques for calculating gradient and aspect from a gridded digital elevation model. Int $\mathrm{J}$ Geogr Inf Syst 3(4):323-334. https://doi.org/10.1080/02693798908941519

Solomon H (2005) GIS based Surface Run-off modelling and Analysis of contributing factors: A Case Study of Nam Chun Watershed, Thailand. International Institute for Geo-Information science and earth observation Enschede, The Netherlands, pp. 1-110 
Stuebe MM, Johnston DM (1990) Runoff Volume estimation using GIS techniques. J Am Water Resour Assoc 26(4):611-620. https://doi.org/10.1111/j.17521688.1990.tb01398.x

Su B, Huang H, Li Y (2015) Integrated simulation method for waterlogging and traffic congestion under urban rainstorms. Nat Hazard 81:23-40. https://doi.org/10.1007/s11069-015-2064-4

Tarboton DG (1997) A new method for the determination of flow directions and upslope areas in grid digital elevation models. Water Resour Res 33(2):309-319. https://doi.org/10.1029/96WR03137

Tran D, Xu D, Dang V, Alwah AAQ (2020) Predicting Urban Waterlogging Risks by Regression Models and Internet Open-Data Sources. Water 12(3):879. https://doi.org/10.3390/w12030879

Vizzari M, Hilal M, Sigura M, Antognelli S, Joly D (2018) Urban-rural-natural gradient analysis with CORINE data: An application to the metropolitan France. Landsc Urb Plan 171:18-29. https://doi.org/10.1016/j.landurbplan.2017.11.005

Vojtek M, Vojteková J (2016) GIS-based Approach to Estimate Surface Runoff in Small Catchments: A Case Study. Quaest Geogr 35(3):1-20. https://doi.org/10.1515/quageo-2016-0030

Warren SD, Hohmann MG, Auerswald K, Mitasova H (2004) An evaluation of methods to determine slope using digital elevation data. Catena 58:215-233. https://doi.org/10.1016/j.catena.2004.05.001

Xue F, Huang M, Wang W, Zou L (2016) Numerical simulation of Urban Waterlogging Based on Flood Area Model. Adv Meteorol 3940707. https://doi.org/10.1155/2016/3940707

Zhao G, Gao J, Tian P, Tian K (2009) Comparison of two different methods for determining flow direction in catchment hydrological modelling. Water Sci Eng 2(4):1-15. https://doi.org/10.3882/j.issn.1674-2370.2009.04.001

Zhou Q, Pilesjö P, Chen Y (2010) Estimating surface flow paths on a digital elevation model using a triangular facet network. Water Resour Res 47(7):1-12. https://doi.org/10.1029/2010WR009961 